Article

\title{
Directions and Challenges in the Management of Municipal Sewage Sludge in Poland in the Context of the Circular Economy
}

\author{
Ksymena Rosiek ${ }^{(D)}$ \\ Department of Industrial and Environmental Policy, Cracow University of Economics, 27 Rakowicka Street, \\ 31-510 Krakow, Poland; ksymena.rosiek@uek.krakow.pl \\ Received: 17 February 2020; Accepted: 24 April 2020; Published: 2 May 2020

\begin{abstract}
Landfilling was the main method of sewage sludge disposal in Poland for decades. After Poland's accession to the European Union (EU), many investments have been made into providing better access to tap water as well as to collect and treat municipal sewage. However, sewage sludge treatment has not been treated as an integral part of the implementation of wastewater management obligations. Stricter European Union regulations regarding the management of municipal sewage sludge (MSS) pose new challenges for Poland. The aim of this study was to analyze changes in the direction of the final management of municipal sewage sludge in Poland based on the analysis of strategic documents, regulations, literature, and available statistical data. The aim of the analysis was to search for directions to modify how sewage sludge is managed, given the approach promoted by the circular economy concept. The results prove that investments in wastewater treatment plants according to the EU sewage directive are not applied to the development of infrastructure that would enable the disposal of sewage sludge, which, for many years, has been stored (landfilling) or used directly in agriculture and ground reclamation. The introduction of stricter regulations in the area of sewage sludge usage and better wastewater treatment have increased the level of difficulties concerning sewage sludge management. Poland faces the challenge of defining sewage sludge management directions. The circular economy concept offers an approach that can be the basis for the creation of a new sewage sludge management strategy for Poland. The concept allows the combined goals of sewage sludge disposal and of energy and nutrients recovery to be achieved.
\end{abstract}

Keywords: sewage sludge; municipal wastewater treatment; Poland

\section{Introduction}

With its accession to the European Union (EU), Poland intensified its efforts to expand its municipal sewage infrastructure and sewage treatment process. The increase in the level of socio-economic development of Poland as well as water and sewage investments, including the construction and modernization of sewage treatment plants, are the main factors affecting the increase in water abstraction and sewage production in the municipal sector, thus increasing the amount of generated municipal sewage. The rising prices of water supply and sewage collection are, in turn, important factors limiting this trend.

While municipal sewage sludge (MSS) accounts for a small percentage of total waste production, its impact on the environment and the risks involved in the process of its use are considerable. Despite many postulates of scientists and practitioners, Poland did not have an integrated strategy for sewage sludge management by the end of 2018, and the requirements in this area, including the ban on the landfilling and limitation for agricultural use, are constantly growing. 
The aim of this study was to analyze changes in the approach to sewage sludge in the municipal economy in Poland based on strategic documents and available statistical data. The aim of the analysis was to search for directions for modifying how sewage sludge is handled given the approach promoted by the circular economy concept, which can be implemented in Poland. An additional purpose of this study was to review legal acts in this field that affect the directions of actions on sewage sludge management.

\section{Sewage Sludge as an Element of Resources Management in the Circular Economy Concept}

The dominant management model shaped by the civilization process is linear, based on the take-make-consume and dispose scheme. This approach could work with a relative availability of resources (relative abundance of resources, low acquisition costs, and significant environmental opportunities for receiving and disposing of waste). The increases in the population and both the standard and length of living, as well as widespread consumerism, contribute to the rapid growth of restrictions that prevent further functioning of the linear model of the economy. This is not a fashionable concept, but ruthless haste drives us toward the circular economy.

Boulding introduced a precursor to the concept of the circular economy in his article "The Economics of the Coming Spaceship Earth" [1] (p. 129-131); [2] (p. 336-337) indicated that in the last century, the economy has been unsustainably developing, and economic models do not consider the depletion of resources and pollution deposited in the environment. As there are no unlimited reservoirs of resources or the possibility of disposing of waste, the Earth is a lonely spacecraft with limited specific resources and a specific capacity of pollutant emissions; thus, the economic system should be changed and production efficiency and consumption should be minimized. Therefore, the measure of economic success is the availability and quality of capital, as well as the well-being of the population.

Many economists have dealt with the theories that became the foundation of building the circular economy. For instance, Ayres and Kneese expanded the theoretical analysis in economics and introduced material balance analysis, including energy flow analysis [3,4] (p. 649); [5] (p. 59).

In 1990, Pearce emphasized the importance of four functions provided by the environment: amenity value, a resource base for the economy, a sink for residual flows, and a life support system. The environment has value in itself, but the neoclassical economic analysis of the environment uses an anthropocentric approach, with an emphasis on the usefulness of the environment for people, measured in terms of economic well-being. Therefore, the relationships between these four functions of the environment were emphasized and the focus was on their valorization [6] (p. 135). In the breakthrough work of Leontief, The Economy as Circular Flow [7], their achievements were later used, among others, in input-output analysis.

The concepts that were particularly important for the development of the circular economy [8] are listed below:

1. Laws of ecology—by B. Commoner in the book The Closing Circle: Nature, Man, and Technology from 1971 [9];

2. Regenerative design - by J.T. Lyle in the book Regenerative Design for Sustainable Development [10];

3. Industrial ecology—by T.E. Graedel in the article "On the Concept of Industrial Ecology" [11];

4. Cradle to Cradle-by W. McDonough and M. Braungart in the book Cradle to Cradle: Remaking the Way We Make Things from 2002 [12];

5. Biomimicry—by J.M. Benyus in the book Biomimicry: Innovation inspired by nature [13];

6. Looped and performance economy - by W. Stahel in the book The Performance Economy [14]; and

7. The blue economy—by G.A. Pauli in the book The Blue Economy: 10 Years, 100 Innovations, 100 Million Jobs [15].

Particular attention should be paid to Stahel and his Performance Economy Concepts [14], in which the possibility is shown of improving prosperity and increasing employment while reducing pressure 
on the environment based on the functional service economy (FSE) model. Their considerations are based on the distinction between flows and stocks, and indicates not only the importance of their quantity, but, above all, their quality. The author emphatically calls them "river" and "lake", which refer to broadly understood types of capital in the economy: natural, human, cultural, financial, and anthropogenic. The FSE, as part of the discussed concept, should be understood as a set of innovative business models that combine and integrate the product and service due to which new local jobs are created and environmental resources are saved, as the manufacturer here is interested in extending the life of the product $[14,16]$.

The circular economy is, by definition, reproducible and renewable, and its aim is to permanently maintain the value and usability of products, components, and materials in separate biological and technical cycles. The technical cycle is understood as the management of inventories of non-renewable materials from which most materials are recovered, but that have previously been used, refurbished, improved, and modernized many times. Use replaces consumption. The biological cycle concerns streams of renewable materials. Consumption only occurs in the biological cycle; renewable (biological) components are mostly regenerated [17] (p. 2-6).

The circular economy is based on a model in which resources are repeatedly used, circulate in the economy; it is a "reuse, repair, and recycle" scheme in which only residual waste, i.e., that which cannot be used in any way, is disposed. Design is crucial not only in the sense of designing the product for its easier recycling and reducing of the amount of waste generated, but also in designing the life cycle of the product for its cascading use.

Moving to the circular economy requires in-depth knowledge of the processes occurring between the environment and the economy as well as society, which should enable identification of areas where the greatest savings can be achieved through proper processes and products projects. An important element of the process is the proper designing stage so that resources in the economy can be retained and, ultimately, raw materials can be recycled. Changing consumer models (use own, consume less and better) and business models (building a relationship with the customer, company responsibility for the product) is necessary to access verified information, to secure the interests of all parties, and to facilitate the creation of secondary raw materials markets (tax preferences). All these challenges can only be met with the intentional support of public authorities by implementing requirements and incentives, as well as economic instruments with a strong stimulus function (taxes) and dissemination of information (education, certification, marking).

The circular economy sub-targets include [18] (p. 4, 5); [19] (p. 7-10):

1. light weight - limiting the amount of materials required to provide a specific service;

2. durability-increasing durability and extending the life of products;

3. efficiency-increasing the efficiency of resource use by reducing energy and materials consumption at the stages of production and use;

4. substitution-limiting the use of hazardous or recyclable materials in products and production processes;

5. market support—creating markets for secondary raw materials (recyclates), e.g., by implementing standards and certificates (e.g., in construction) or using green public procurement;

6. ecodesign-designing products that are easier to maintain, repair, upgrade, remake, or recycle;

7. maintenance-supporting the development and increasing the accessibility of services for consumers, e.g., maintenance and repair;

8. waste prevention - encouraging consumers to reduce waste generation;

9. waste management-encouraging segregation and the use of collection systems that minimize the costs of recycling and re-using;

10. industrial symbiosis-facilitating the grouping of activities aimed at preventing the disposal of by-products for waste;

11. sharing — promoting sharing; use rather than own to secure consumer interests; and 
12. reusability - promoting innovative business models that may lead to new relationships between enterprises and consumers in order to create a new and repeatable model.

In the field of waste, many mechanisms toward the implementation of the main circular economy objective have already been implemented, such as a waste hierarchy, increasing the efficiency of separate collection systems, or fees for additional packaging or its return. Despite this, much remains to be completed to stimulate the reduction of waste generation and the re-use of obtained secondary raw materials. However, associating the circular economy with waste (the final stage of the process) is a simplification, and even a mistake. The circular economy focuses primarily on resources (the initial stage of the process), their use, and the maintenance of their value in circulation in the economy. This means that the circular economy focuses on the most effective use of environmental resources and guarantees the multiple use of resources circulating in the economic system so that waste in the sense that we understand it today (i.e., the flow of mixed organic and non-organic stocks) is generated on a very limited scale.

The designing stage itself guarantees an easy option of repair, modernization or types of dismantling that ensures good quality resources are delivered to other manufacturers. In this way, the manufacturer takes the responsibility for resource management instead of shifting it onto the local community, as is often done today.

Sewage sludge as a waste group fits perfectly into the subject of interest in the circular economy. Its amount increases due to the rising number of sewage treatment plants, the quality of the treatment process, and the residents served. It is a type of waste that contains recoverable substances (e.g., nitrogen or phosphorus). Although this technology is still expensive, technological progress will make it achievable soon.

Changes in the level of knowledge and available technologies affect the limitation of the existing forms of use of sludge (agricultural use, composting), and the forms of use with the recovery of resources and energy are preferable.

\section{Materials and Methods}

This paper contains a critical analysis of sewage sludge management in Poland on the basis of legislation and strategic document analysis regarding specific Polish solutions and indicating their cause. The statistical data available in national statistics (the Polish Central Statistical Office (stat.gov.pl) and Local Data Bank Database (bdl.stat.gov.pl) were used for further analysis, supported by detailed explanations based on data and clarifications obtained directly from the Central Statistical Office.

\subsection{The Scope of Definitions of Sewage Sludge in Polish Legislation}

Despite the development of municipal sewage management infrastructure (MSS) in Poland, sewage sludge has not been treated as an integral part of the wastewater treatment process for a long time, which means that often, when taking up investments in the field of municipal wastewater treatment, no sewage sludge treatment method has been planned. The actions taken in the 1990s in Poland resulted in slow changes aimed at closing the process of wastewater treatment in its final phase. Up until 1999, the MSS was not monitored, and 2002 marked the beginning of a sewage sludge registry system in Poland [20,21] (p. 416). Trends in the directions of sewage sludge management will be discussed later in this paper, but at this stage it should be noticed that in the early 1990s, the landfilling of sewage sludge was a major utilization method. Nowadays, due to the tightening of EU and Polish law, as well as the availability of technologies and funds, the process of searching for and selecting other methods of MSS management is underway.

The legal basis for the management of MSS in Poland consists of:

1. The Water Law [22],

2. The Waste Act [23], and

3. The Act on collective water supply and collective sewage disposal [24]. 
In Polish legislation, the issue of handling MSS is primarily regulated by the Waste Act [23], article 2, paragraph 8, as opposed to sewage, which is excluded from the scope of this Act, as are some biomass fractions; however, in state statistics, they are listed in the resources, use, pollution, and water protection section, not in the waste section. The Act defines MSS as waste sludge from fermentation chambers and other installations for the treatment of municipal wastewater and other wastewater with a composition similar to municipal wastewater [23] (article 3, paragraph 4). It also defines the term "using municipal sewage sludge" as the spreading of municipal sewage sludge on the surface of the earth or the disposal into the soil [23] (article 3, paragraph 28). All other processes, such as thermal treatment of waste, are regulated by other provisions of this Act [23] (articles 155-163).

The Waste Act devotes one chapter to municipal sewage sludge [23] (Chapter 4). It specifies how sewage sludge can be used as part of recovery [23] (article 96):

1. in agriculture, understood as the cultivation of all agricultural crops placed on the market, including crops intended for the production of feed, and for the cultivation of plants intended for the production of compost;

2. for the cultivation of plants not intended for consumption, and for the production of feed;

3. for the reclamation of land, including land for agricultural purposes; and

4. when adapting the land to specific needs resulting from waste management plans, spatial development plans, or decisions on building and land development conditions.

The Act includes a number of detailed regulations regarding the principles of safe sewage sludge management in recovery processes, for example, that sludge can be transferred for use only by the producer. Responsibility for its testing and proper use also rests with the producer (wastewater treatment plant), who must inform the Inspectorate of Environmental Protection about the intention to use such sludge [23] (article 96, items 2-11).

The Act also includes exclusion areas where sewage sludge cannot be used, which include, in general, places in the close proximity to protected areas, water intakes, areas with large falls, near water bodies and wetlands that are particularly at risk of experiencing floods or flooding, as well as on high permeability soils. Restrictions also exist in areas with specific types of crops intended for consumption [23] (article 96, paragraph 12).

The provisions of the Act are clarified, among others, by the following regulations:

1. Regulation on municipal sewage sludge [25];

2. Regulation on the criteria of waste admission for landfill [26];

3. Regulation on the recovery process R10 [27];

4. Regulation on the recovery of waste outside treatment installations and equipment installations and equipment [28];

5. Regulation on the implementation of certain provisions of the Act on fertilizers and fertilization [29];

6. Regulation on the waste catalogue [30];

7. Regulation on types of waste that can be deposited in a landfill in a non-selective manner [31];

8. Regulation on conditions to be met when introducing sewage into waters or into the ground, and on substances particularly harmful to the aquatic environment [32];

9. Regulation on the manner of fulfilling the obligations of industrial sewage supplier and the conditions for the introduction of wastewater to sewage systems [33]; and

10. Regulation on methods of conducting the assessment of soil surface pollution [34].

The rules for the use of sewage sludge in agriculture can also be found in the Act of 10 July, 2007 on fertilizers and fertilization [29]. Certain issues are regulated by the Water Law Act including reports, sludge quality tests, water permits, and sewage sludge within its scope (but also in this Act, sewage sludge is included directly in fertilizers) [22] (article 102 (2)). 
From the point of view of the direction of sewage sludge use, the regulations resulting from energy law and obligations connected with $\mathrm{CO}_{2}$ emission reductions are also important, as sewage sludge is considered to be a biomass and a renewable and $\mathrm{CO}_{2}$-free energy source [35]. The definition of biomass is not specified in the current Act on Waste, but the definition of biodegradable waste is understood as waste that is subject to aerobic or anaerobic decomposition with the participation of microorganisms. Two other definitions can be found in Polish legislation: the scope of biomass definitions in regulations on emission standards and renewable energy certificates [36], which refer to Directive 2009/28/EC on the promotion of the use of energy from renewable sources, where a broad definition of biomass, including sewage sludge, is given [37]. The Waste Catalogue indicates groups of wastes not belonging to municipal wastes, and that are deemed to be biodegradable ([30,38], p. 58):

1. 02-wastes from agriculture, horticulture, hydroponics, fishery, forestry, hunting, and food processing;

2. 03 - waste from wood processing and the production of panels and furniture, pulp, paper, and cardboard; and

3. 19-waste from installations and devices used for waste management, from wastewater treatment plants and treatment of drinking water and water for industrial purposes.

Therefore, since sewage sludge is a biomass, it should be treated as a renewable and $\mathrm{CO}_{2}$-free source of energy [39] (p. 90). This impacts the directions of its use, because, for example, cement plants are interested in the combustion of sewage sludge. However, the price of certificates matters here.

When defining sewage sludge, one should refer to many legal acts, and in practice, many problems exist with the eligibility criteria, i.e., when sewage sludge becomes waste and when it stops being waste. There are equally as many problems with the attribution of recovery and recycling processes. Sludge processing includes the issues of processing and further processing, transformation and use, and applies to both recovery and disposal methods without endangering human health and without harming the environment. In the case of sewage sludge, assigning a given process to the group of recovery or recycling methods in accordance with the Polish law is difficult and disputable. Depending on the method of final management, the fermentation process can be considered for disposal once sludge are burnt or for recovery if the sewage sludge is then used, for example, for fertilization or land reclamation [40] (p. 112). All of these nuances make the credibility of the data collected in the national statistic system questionable. In addition the term "municipal sewage sludge" can be misleading too. This kind of sludge is generated in industrial plants (wastewater treatment plants), and not directly in households and therefore should be categorized as industrial, waste. However, strategic documents as well as the public statistics classify it as being municipal waste, a definition which is widely accepted.

\subsection{Changes in Programming Sewage Sludge Management in Poland}

Despite the Strategy for Municipal Sewage Sludge Treatment being introduced in Poland [41], the following documents should be considered:

1. National Waste Management Plan (NWMP) [21,38]. There are adequate documents at the local level. The first National Waste Management Plan was adopted in 2002 (another actualization in 2006, 2010, 2015) and the current NWMP 2022 was adopted in 2017,

2. National Waste Prevention Programme (NWPP) [42],

3. The Polish Energy Policy until 2030 (PEnP) [43],

4. National Municipal Wastewater Treatment Programme (NMWTP) [44].

Some differences exist in the approach to managing MSS in the NWMPs of 2002 [21] and 2016 [38]. The 2002 NWMP, however, lacks the integration of MSS management and the sewage treatment process and provisions regarding the optimization of the amount of sewage sludge formed in the wastewater treatment process. According to the given statistical data, the dominating part of sewage sludge is 
collected in the area of a sewage treatment plant $(42 \%)$, and the most common form of disposal is agricultural use. The Plan provides for a two-fold increase in the amount of sludge, and outlines the directions of activities aimed at reducing the amount of sludge collected. It is indicated that due to the composition of MSS, its usage in agriculture will decrease and the preferred direction of development is for increased composting [21].

The 2016 NWMP confirms the trend of the increase in sewage sludge. The plan indicates that minimizing the amount of generated MSS is often treated as a secondary issue in sewage treatment plants, and that the method of the final disposal of sewage sludge changes (the share of combustion increases, the share of landfilling decreases, and the share of agricultural use remains). Still, the sludge is collected in significant quantities in treatment plants [38].

In connection with the tightening of the regulations concerning the possibility of agricultural use of municipal sewage sludge [23] (article 96 (12.8)), it is expected that the share of this form of sludge management for combustion will decrease. The possibility of landfilling sewage sludge is also legally restricted [26]. In the 2016 NWMP, the following objectives are adopted [38] (p. 103):

8. complete cessation of municipal sewage sludge storage (landfilling);

9. increasing both the amount of municipal sewage sludge treated prior to entering the environment and the amount of municipal sewage sludge subjected to thermal transformation; and

10. striving to maximize the use of biogenic substances contained in sewage sludge, while meeting all the requirements concerning sanitary, chemical, and environmental safety.

These goals are in line with the guidelines set by the European Union.

The Plan stresses the necessity of approaching sewage sludge in accordance with the waste management hierarchy, thus preventing its formation (Table 1), which is a significant change compared to the first NWMP. At the same time, it is pointed out that the National Municipal Wastewater Treatment Programme (NMWTP) [44] needs to further address the issue of municipal sewage sludge treatment, which has not yet obtained the status of waste, and to indicate the need to specify the directions of its development in water permits.

Table 1. Directions for the management of municipal sewage sludge in accordance with the hierarchy of municipal waste management.

\begin{tabular}{|c|c|c|}
\hline No. & Hierarchy of Waste Management & Examples of Processes \\
\hline 1 & prevention & $\begin{array}{c}\text { By subjecting sludge to such processes as disintegration, } \\
\text { deep stabilization, hygienization, and dehydration, } \\
\text { or activities aimed at removing the waste status in such a } \\
\text { way that sewage sludge can be intended, for example, } \\
\text { for organic fertilizers }\end{array}$ \\
\hline 2 & recycling & $\begin{array}{l}\text { Organic recycling, including composting of the sewage } \\
\text { sludge with other wastes in order to obtain material after } \\
\text { the composting process used for fertilizing purposes, } \\
\text { and mineral recycling with phosphorus recovery or in } \\
\text { cement-making plants }\end{array}$ \\
\hline 3 & recovery & $\begin{array}{l}\text { Recovery directly on the ground after compliance with } \\
\text { certain conditions, including recovery in composting } \\
\text { plants, biogas plants, or cement plants; energy } \\
\text { recovery_for sludge as biomass, this means incineration } \\
\text { or recovery outside installations }\end{array}$ \\
\hline 3 & disposal & $\begin{array}{l}\text { Thermally transformed into waste incineration plants or } \\
\text { co-incineration plants, without energy recovery or being } \\
\text { stored, after processing, where they comply with the } \\
\text { requirements laid down in the legislation }\end{array}$ \\
\hline
\end{tabular}


The National Municipal Wastewater Treatment Programme of 2003 [44] (p. 24) balanced the needs related to water and sewage management, including the management of MSS in the context of planned investment needs. In principle, only the forecast of the amount of sewage sludge for 2015 is included. Investment plans include separate investments related to the modernization of sewage sludge management (41 items), but similar investments may be hidden in other positions, such as in the construction of sewage treatment plants. The 2017 NMWTP mainly refers to the above-mentioned changes in regulations, limiting the existing sludge management methods, and points to the possibilities related to innovative methods of sewage sludge management, such as the production of advanced biocomponents [45] (p. 27). However, these entries cannot be treated as determining the directions of sewage sludge management. The issues of sewage sludge are not treated as a priority in these documents.

NMWTP has been updated many times and is now on its fifth update, showing a significant change in the approach to the management of sewage sludge, both at the level of defining the scope, the program (the method of dealing with settlements is one of the subjects of evaluation) [45] (p. 20), and the number of planned investments (318 separated investments, which gives almost eight-fold increase) [45] (p. 24). However, the increase in the presence of sewage sludge in this document is not in line with expectations and needs.

Another important document is the National Waste Prevention Programme (NWPP), which defines the priority area for action in the form of [42] (p. 16-17):

1. Waste from extractive and physical and chemical industries;

2. Processing of ores and other minerals;

3. Wastes from thermal processes (energy);

4. Hazardous wastes, including wastes from the chemical industry and wastes of chemical agents;

5. Municipal waste;

6. Packaging waste;

7. Food waste; and

8. Waste from electronic equipment.

A further analysis of the document shows that sewage sludge is not counted as municipal waste. In the entire text of the strategy, sewage sludge is not mentioned; it appears only in the annex of the strategy "State diagnosis for specific waste groups", where it was included in the "other waste" group. This indicates the expected increase in the amount of sewage sludge and the difficulty in counteracting this trend. As a direction of action, the purification process should be modified: the analysis of the quality of the effluent, the stabilization and optimization of sludge dehydration, the reduction of the amount of pathogens, and the recovery of phosphorus and nitrogen. The thermal conversion of sewage sludge, where this may be economically justified [42] (p. 89-90), should also be considered.

The Polish Energy Policy until 2030 (PEnP) points out that it is important to develop renewable energy sources, including biomass (and in particular, the use of biogas from landfills, wastewater treatment, and other wastes) [43] (p. 18-19). In contrast, sewage sludge is not indicated as a biomass or a zero-emission source of energy.

In conclusion, in Poland, strategies focus more on solving wastewater problems and implementing sewage directives than on the management of sewage sludge. The provisions relating to the reduction of sewage sludge landfilling and their agricultural use have been implemented, but clear direction for sewage sludge management is lacking, which would facilitate the acquisition of financial resources for such investments, as well as research on new technologies and monitoring. Also, it would support the solution of the sewage sludge problem in Poland more clearly.

At the end of 2018, the Strategy for Municipal Sewage Sludge Treatment for the years 2019-2022 was adopted [41]. The expert community postulated a comprehensive document covering all issues related to the management of sewage sludge [46]. Unfortunately, the scope of the strategy is limited and does not correlate with an integrated approach to the actual solution of the problem. The document 
has 37 pages, 30 of which regard the diagnosis and analysis of the legal acts, without solving any definitional doubts.

The subject of the strategy is [41] (p. 3): creating conditions and setting up mechanisms conducive to the solution of the growing problem of urban sewage sludge disposal. The scope of the strategy's tasks focuses on the processes of municipal sewage sludge processing as waste.

The strategic objectives are defined correctly [41] (p. 33):

1. Prevention and reduction of the amount of sewage sludge resulting from wastewater treatment plants and the elimination of the production of municipal sewage sludge, which, due to the quality, creates problems with its management in accordance with regulations, through thermal transformation, use on the surface of the earth, production of fertilizers or plant-support products, or others.

2. Increasing the amount of municipal sewage sludge processed before entering the environment and increasing the amount of municipal sewage sludge incinerated.

3. Striving to maximize the use of nutrients contained in sedation, while meeting all requirements for sanitary, chemical, and environmental safety.

Four groups of tasks were adopted, and their implementation is planned until the end of 2022 [41] (p. 34):

1. Consideration of the need to amend the ordinance of the Minister of the Environment regarding municipal sewage sludge in the scope of determining the stabilization parameters of municipal sewage sludge and clarifying the provisions concerning the frequency and methodology of municipal sewage sludge tests.

2. Consideration of the need to amend the Waste Act regarding:

(1) reduction of odor nuisance resulting from the use of municipal sewage sludge;

(2) extension of the scope of documentation regarding the actual use of municipal sewage sludge;

(3) introduction of an obligation to use only sewage sludge from a single producer on the plot;

(4) extension of information contained in the application for the use of municipal sewage sludge transferred to the Regional Inspectorate of Environmental Protection;

(5) adding an obligation to obtain a waste treatment permit for a land-wielding landlord on which municipal sewage sludge will be used; and

(6) tightening of sanction regulations.

3. Execution of controls regarding the compliance of wastewater treatment plants, with provisions regarding waste management in relation to municipal sewage sludge, including possession and observance of permit conditions for waste treatment in the treatment plant.

4. Conducting training for the management of sewage treatment plants in the field of municipal sewage sludge management after obtaining waste status.

Although these issues are important, they do not solve or even attempt to point in the direction of actions that should be taken to solve the problems of sewage sludge management in Poland, like [46]:

1. Resolving sewage sludge issues from home wastewater treatment plants, as they should be treated as liquid impurities;

2. Investments in the construction or modernization of the sludge lines of sewage treatment plants (pre-treatment);

3. Utilizing technologies for the pre-treatment of sewage sludge, which are an integral part of wastewater in the technological processes of wastewater treatment plants, resulting in the prevention of waste; 
4. Using sewage sludge disintegration technologies and phosphorus recovery technologies from sewage sludge, which are an integral part of wastewater, as well as water removal technologies (compaction, dewatering conditioning);

5. Employing forms of sewage sludge treatment, which is an integral part of wastewater in the technology of wastewater treatment plants, such as hygiene and stabilization; and

6. Resolving issues of construction and modernization of sewage treatment plants, introducing find solutions for sewage sludge.

These issues are important for the management of such waste as sewage sludge because its treatment on the site of the wastewater treatment plant is important for the final development. However, these issues are not the responsibility of Minister of the Environment (which prepared the strategy), but rather the responsibility of the minister responsible for water management. As a result, the necessary horizontal and integrated approach has never been adopted; instead, a narrow sectoral approach is currently preferred. Again, there are no ideas for a solution to the problem of sewage sludge management.

\section{Discussion}

\section{Changes in the Stream and Direction of Using Sewage Sludge in Poland}

The amount of MSS generated in municipal wastewater treatment plants depends on the quantity and quality of wastewater discharged to the wastewater plant. Therefore, it depends on the number of inhabitants and other entities connected to the sewage system, the technological processes (effectiveness of purification), and other factors related to the industrialization of the site and the type and technical condition of the sewage system. The directions for the zoning of sewage sludge are also changing (Figure 1). Their physical, chemical, and biological properties, including those related to sanitary safety, are influenced by the possibilities and methods of sludge treatment. They also depend on how MSS is managed and the methods for optimizing the processes leading to a reduction in its quantity and quality changes; all of these factors determine the final treatment methods. Technological changes and tightening of legislation are also important criteria for the choice of sewage sludge treatment.

Sewage sludge is formed at various stages of wastewater treatment and, in general, can be divided into waste from scrubby, sandstone, sludge stabilization, and dewatering processes, including stabilized municipal sewage sludge. The Polish Central Statistical Office (CSO, stat.gov.pl) does not publish data on sewage sludge by type, but does provide information on the directions for its development.

The CSO publishes data on the production of wastewater and sewage sludge, both industrial and municipal, where a significant proportion of industrial wastewater is cooling water. Therefore, data on the production of wastewater without cooling water are also presented to the industry (Figure 1).

In the urban wastewater stream, there is also some forms of industrial wastewater as well as rainwater. Rainwater from industrial and polluted areas is particularly important. Although this article focuses on municipal sewage sludge, general data are presented on the quantity of sewage and sewage sludge produced, both municipal and industrial, to show the overall picture of the situation for the country. A further analysis covers only municipal sewage sludge. The statistical data for sewage sludge are available only from the year 2000, as they were not published before that time.

The statistics show that after the year 2000, the total amount of wastewater produced was slightly variable and decreased, and in case of municipal treatment plants, the amount of wastewater produced after 2000 decreased to about $163 \mathrm{hm}^{3}$, which is almost $11 \%$ of the total production since 2000 (Table 2 and Figure 1). However, since 2015, this figure has been slowly but steadily growing (Figure 2). 


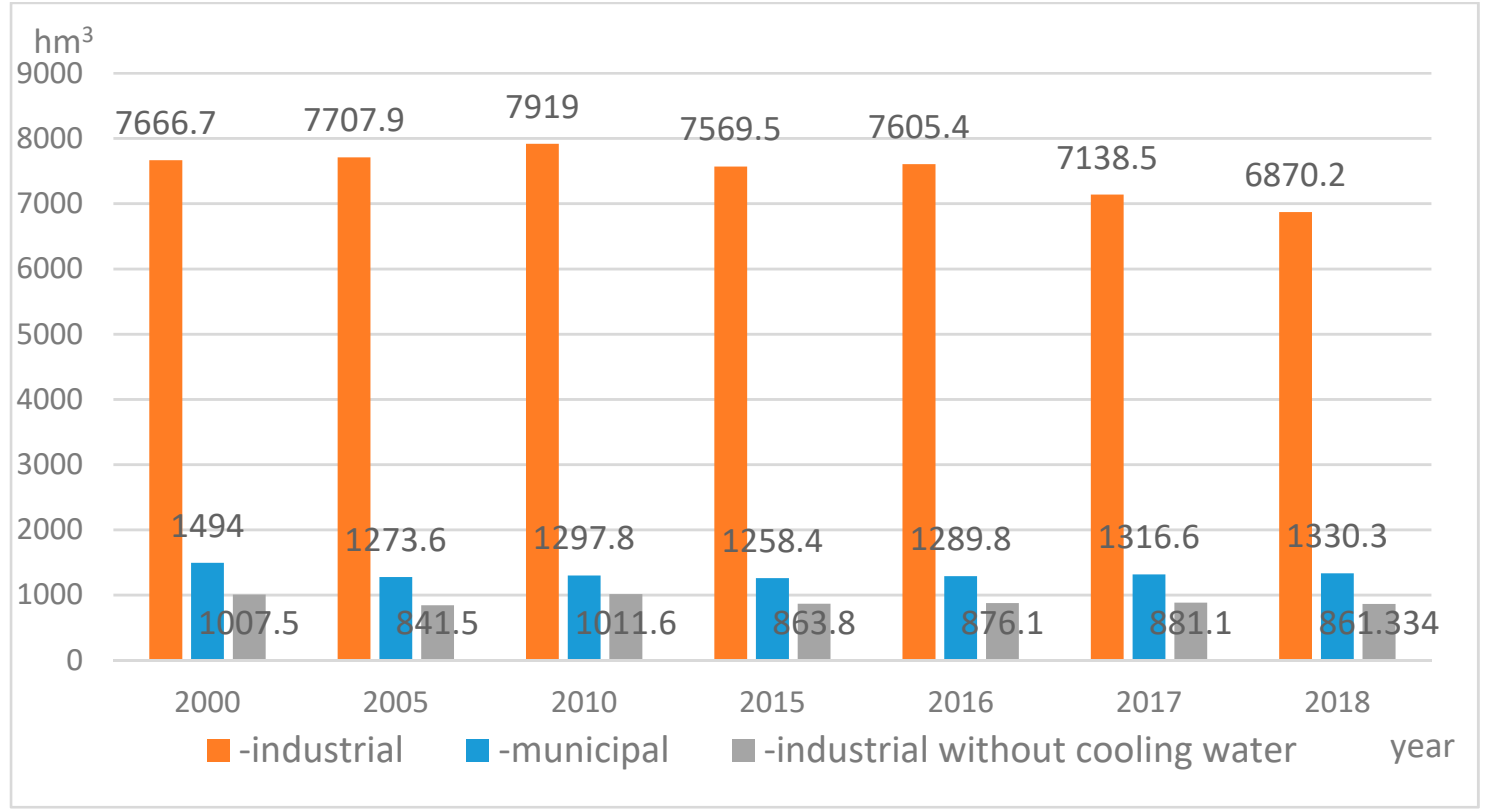

(a)

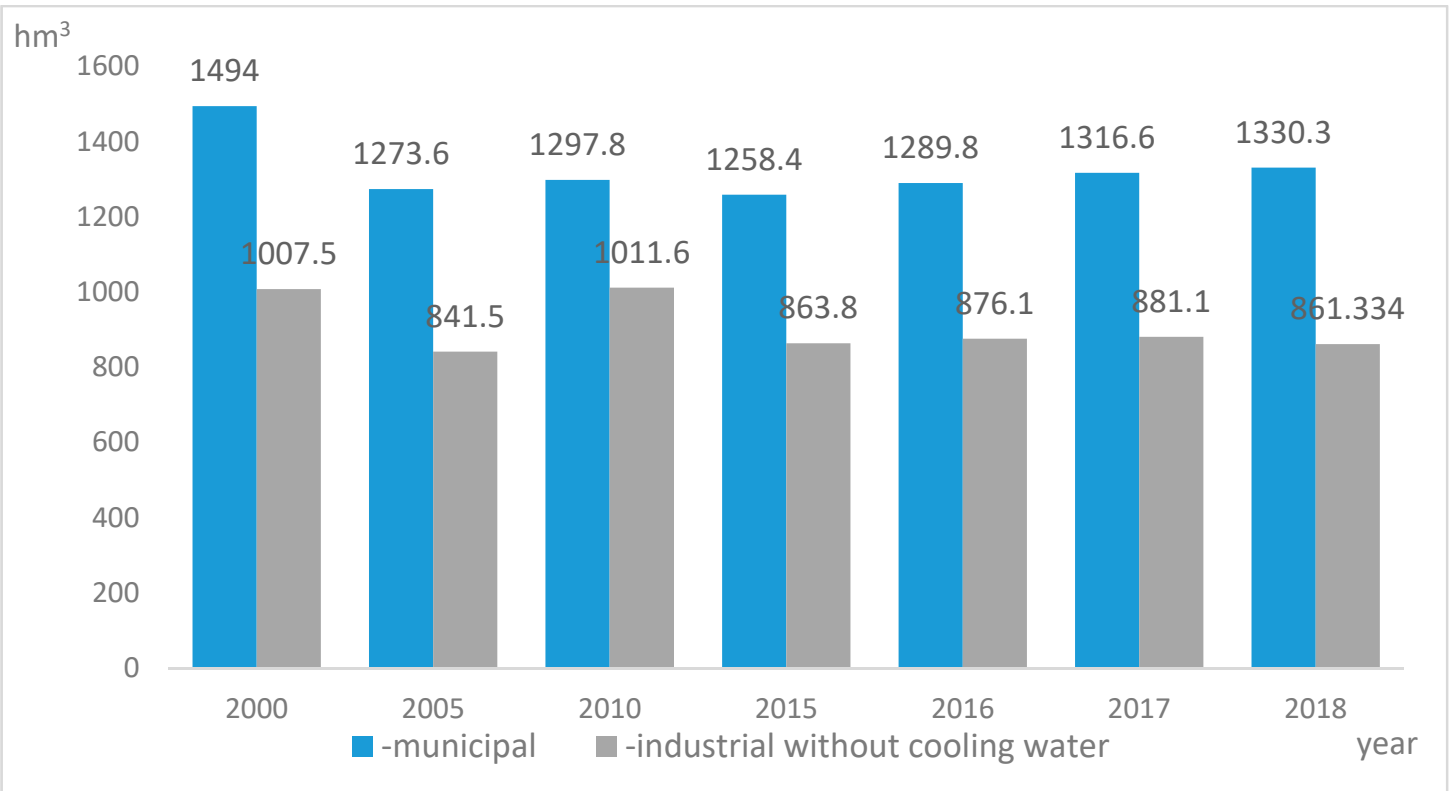

(b)

Figure 1. a. Industrial and municipal wastewater produced in Poland from 2000 to 2018 (in hm $\mathrm{hm}^{3}$ ). b. Industrial and municipal wastewater produced in Poland from 2000 to 2018 without cooling water (in $\mathrm{hm}^{3}$ ). Source: [47], Table 29(75); [48], Table 27(72). 
Table 2. Production and treatment of wastewater, and production and directions of disposal of sewage sludge in Poland in the years 2000-2018.

\begin{tabular}{|c|c|c|c|c|c|c|c|c|c|c|}
\hline Specification & Units & 2000 & 2005 & 2010 & 2015 & 2016 & 2017 & 2018 & $2018 / 2000$ & $2018 / 2010$ \\
\hline \multicolumn{11}{|c|}{ WASTEWATER } \\
\hline Total wastewater generated during the year & $\mathrm{hm}^{3}$ & 9160.7 & 8981.5 & 9216.8 & 8827.8 & 8895.2 & 8455.1 & 8200.4 & 0.895 & 0.890 \\
\hline -industrial & $\mathrm{hm}^{3}$ & 7666.7 & 7707.9 & 7919.0 & 7569.5 & 7605.4 & 7138.5 & 6870.2 & 0.896 & 0.868 \\
\hline -municipal & $\mathrm{hm}^{3}$ & 1494.0 & 1273.6 & 1297.8 & 1258.4 & 1289.8 & 1316.6 & 1330.3 & 0.890 & 1.025 \\
\hline Wastewater requiring treatment (of which): & $\mathrm{hm}^{3}$ & 2501.5 & 2115.1 & 2309.4 & 2122.1 & 2166.0 & 2197.7 & 2191.6 & 0.876 & 0.949 \\
\hline -treated & $\mathrm{hm}^{3}$ & 2200.2 & 1929.4 & 2133.7 & 2015.1 & 2061.3 & 2091.1 & 2085.3 & 0.948 & 0.977 \\
\hline -mechanically & $\mathrm{hm}^{3}$ & 732.7 & 576.1 & 615.7 & 510.4 & 514.0 & 497.4 & 481.7 & 0.657 & 0.782 \\
\hline -biologically & $\mathrm{hm}^{3}$ & 875.9 & 501.8 & 361.8 & 328.2 & 342.4 & 360.8 & 353.8 & 0.404 & 0.978 \\
\hline -biologically with increased biogen removal & $\mathrm{hm}^{3}$ & 460.4 & 742.5 & 1034.4 & 1089.4 & 1117.4 & 1138.0 & 1158.9 & 2.517 & 1.120 \\
\hline -untreated & $\mathrm{hm}^{3}$ & 301.3 & 185.7 & 175.7 & 107.0 & 104.7 & 106.6 & 106.3 & 0.353 & 0.605 \\
\hline \multicolumn{11}{|c|}{ SEWAGE SLUDGE } \\
\hline Total sewage sludge generated during the year & thous. t. d.s. & 1063.1 & 1124.4 & 895.1 & 951.5 & 947.2 & 1035.2 & 1046.5 & 0.984 & 1.169 \\
\hline -applied in agriculture & thous. t. d.s. & (.) & 98.2 & 136.9 & 126.6 & 133.9 & 126.1 & 134.2 & $\mathrm{x}$ & 0.980 \\
\hline $\begin{array}{c}\text {-applied in land reclamation, } \\
\text { including reclamation of land for agricultural } \\
\text { purposes }\end{array}$ & thous. t. d.s. & (.) & 324.9 & 150.4 & 31.3 & 31.7 & 32.1 & 27.8 & $\mathrm{x}$ & 0.185 \\
\hline $\begin{array}{l}\text {-applied in cultivation of plants intended for } \\
\text { compost production }\end{array}$ & thous. t. d.s. & 28.1 & 29.6 & 31.3 & 48.2 & 32.8 & 26.9 & 26.0 & 0.925 & 0.831 \\
\hline -incinerated & thous. t. d.s. & 34.1 & 37.4 & 66.4 & 165.4 & 194.7 & 232.3 & 234.3 & 6.871 & 3.529 \\
\hline - landfilling & thous. t. d.s. & 474.5 & 399.1 & 165.9 & 131.5 & 97.6 & 101.8 & 119.1 & 0.251 & 0.718 \\
\hline $\begin{array}{l}\text {-sewage sludge accumulated in the wastewater } \\
\text { treatment plants (as of the end of the year) }\end{array}$ & thous. t. d.s. & (.) & 9342.8 & 6450.5 & 6483.9 & 6287.0 & 6316.4 & 6229.4 & $\mathrm{x}$ & 0.966 \\
\hline \multicolumn{11}{|c|}{ SEWAGE SLUDGE FROM INDUSTRIAL WASTEWATER TREATMENT PLANTS } \\
\hline Total sewage sludge generated during the year & thous. t. d.s. & 703.3 & 638.3 & 368.4 & 383.5 & 378.9 & 450.7 & 463.5 & 0.641 & 1.223 \\
\hline \multicolumn{11}{|c|}{ SEWAGE SLUDGE FROM MUNICIPAL WASTEWATER TREATMENT PLANTS } \\
\hline Total sewage sludge generated during the year & thous. t. d.s. & 359.8 & 486.1 & 526.7 & 568.0 & 568.3 & 584.5 & 583.1 & 1.621 & 1.107 \\
\hline -applied in agriculture & thous. t. d.s. & (.) & 66.0 & 109.3 & 107.5 & 116.0 & 108.5 & 118.3 & $\mathrm{x}$ & 1.082 \\
\hline $\begin{array}{c}\text {-applied in land reclamation, } \\
\text { including reclamation of land for agricultural } \\
\text { purposes }\end{array}$ & thous. t. d.s. & (.) & 120.6 & 54.3 & 19.2 & 20.1 & 19.7 & 17.4 & $\mathrm{x}$ & 0.320 \\
\hline
\end{tabular}


Table 2. Cont.

\begin{tabular}{|c|c|c|c|c|c|c|c|c|c|c|}
\hline Specification & Units & 2000 & 2005 & 2010 & 2015 & 2016 & 2017 & 2018 & $2018 / 2000$ & $2018 / 2010$ \\
\hline $\begin{array}{l}\text {-applied in cultivation of plants intended for } \\
\text { compost production }\end{array}$ & thous. t. d.s. & 25.5 & 27.4 & 30.9 & 47.1 & 31.8 & 25.9 & 25.2 & 0.988 & 0.816 \\
\hline -incinerated & thous. t. d.s. & 5.9 & 6.2 & 19.8 & 79.3 & 101.1 & 106.2 & 111.5 & 18.898 & 5.631 \\
\hline -landfilled & thous. t d.s. & 151.6 & 150.7 & 58.9 & 40.5 & 20.7 & 15.3 & 10.6 & 0.070 & 0.180 \\
\hline -temporarily stored & thous. t. d.s. & $()$. & 27.3 & 68.2 & 56.4 & 47.3 & 51.3 & 50.0 & $x$ & 0.733 \\
\hline -other & thous. t. d.s. & (.) & 87.9 & 185.3 & 218.0 & 231.4 & 257.6 & 249.9 & $x$ & 1.349 \\
\hline $\begin{array}{l}\text {-sewage sludge accumulated on the wastewater } \\
\text { treatment plants (as of the end of the year) }\end{array}$ & thous. t. d.s. & 675.0 & 782.7 & 332.4 & 246.9 & 221.2 & 219.3 & 0.324 & 0.659 & 0.324 \\
\hline \multicolumn{11}{|c|}{ INDICATORS } \\
\hline Total wastewater generated per capita & $\mathrm{m}^{3} /$ person & 57.5 & 50.6 & 55.4 & 52.4 & 53.6 & 54.4 & 54.3 & $\mathrm{x}$ & $x$ \\
\hline $\begin{array}{l}\text { Total sewage sludge generated in municipal } \\
\text { wastewater treatment plants per capita }\end{array}$ & $\mathrm{kg} /$ person & 9.4 & 12.7 & 13.7 & 14.8 & 14.8 & 15.2 & 15.2 & $\mathrm{x}$ & $\mathrm{x}$ \\
\hline $\begin{array}{c}\text { Total sewage sludge generated in municipal } \\
\text { wastewater treatment plants/inhabitants served } \\
\text { by treatment plants }\end{array}$ & $\mathrm{kg} /$ person & 17.5 & 21.2 & 21.1 & 20.3 & 20.1 & 20.7 & 20.5 & $\mathrm{x}$ & $\mathrm{x}$ \\
\hline sewage sludge generated/p.e.*/year & kg/p.e.* & 27.4 & 29.0 & 23.1 & 24.5 & 24.4 & 26.7 & 27.0 & $\mathrm{x}$ & $\mathrm{x}$ \\
\hline $\begin{array}{l}\text { sewage sludge generated in municipal } \\
\text { wastewater treatment plants/p.e*./year }\end{array}$ & kg/p.e.* & 9.3 & 12.5 & 13.6 & 14.6 & 14.6 & 15.1 & 15.0 & $\mathrm{x}$ & $\mathrm{x}$ \\
\hline sewage sludge generated/wastewater treated & $\mathrm{kg} / \mathrm{m}^{3}$ & 17.5 & 21.2 & 21.1 & 20.3 & 20.1 & 20.7 & 20.5 & $\mathrm{x}$ & $x$ \\
\hline
\end{tabular}

(.) no data available, $x$ - not applicable; population equivalent p.e.- $f$ or the purposes of implementing the provisions of Directive 91/271/EEC, which was set, in 2017, for Poland at 38,793,049. Source: own study based on [47] Table 29(75), 32(76), and 61(107), [48] Table 27(72), 29(74), 30(75), 59(104), 60(105), and 61(106) and [49,50] 26(71), 58(103), 59(104) 


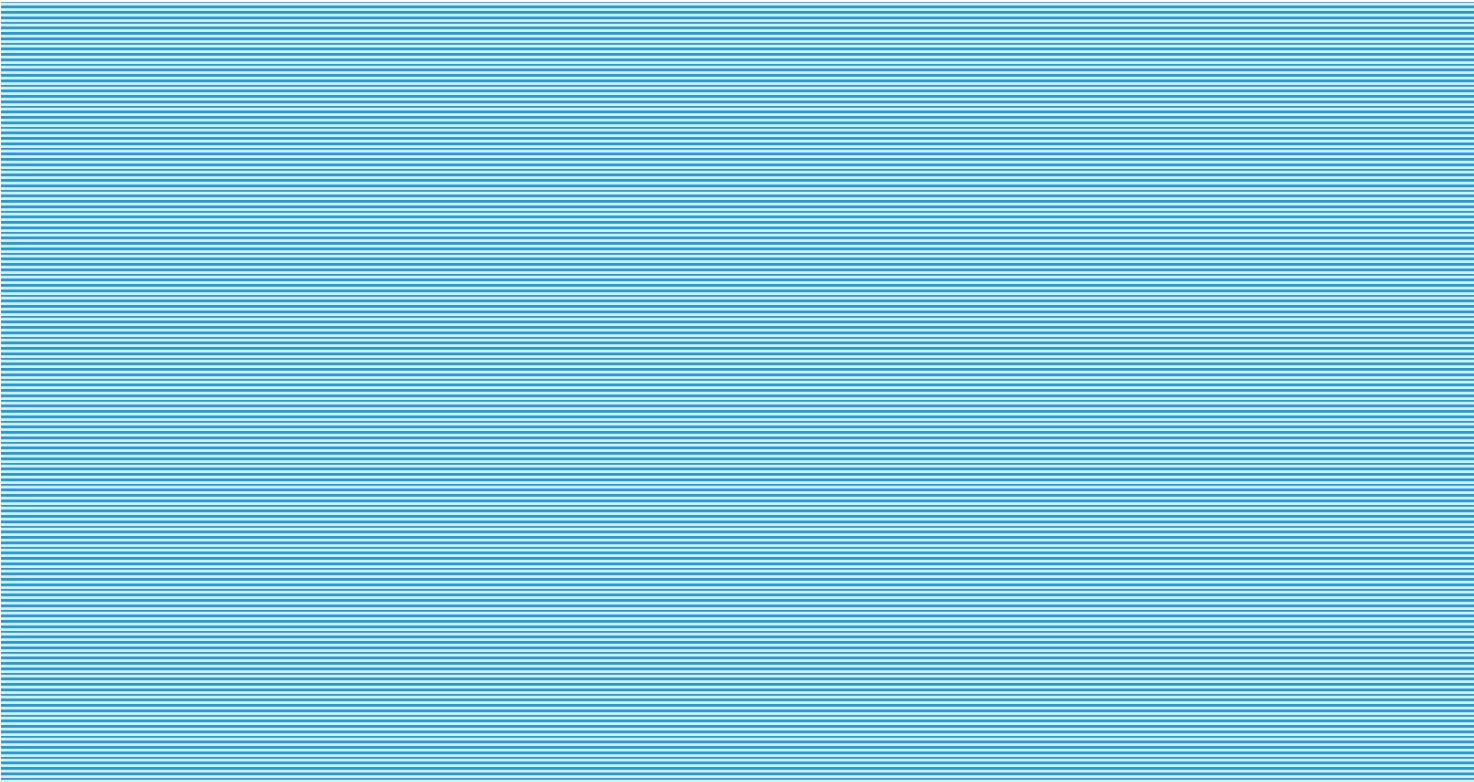

Figure 2. Industrial and municipal sewage sludge produced in Poland from 2000 to 2018 (thousands tons of dry substance). Source: Own development based on [47]) Table 61(107), [48] Table 59(104).

At the same time, the number of people connected to the wastewater treatment plants (Figure 3) increased, and the proportion of the citizens connected to the wastewater treatment plants increased from $56.6 \%$ in 2002 to $74 \%$ in 2018. This is one of the main factors influencing the growth of wastewater and sewage sludge.

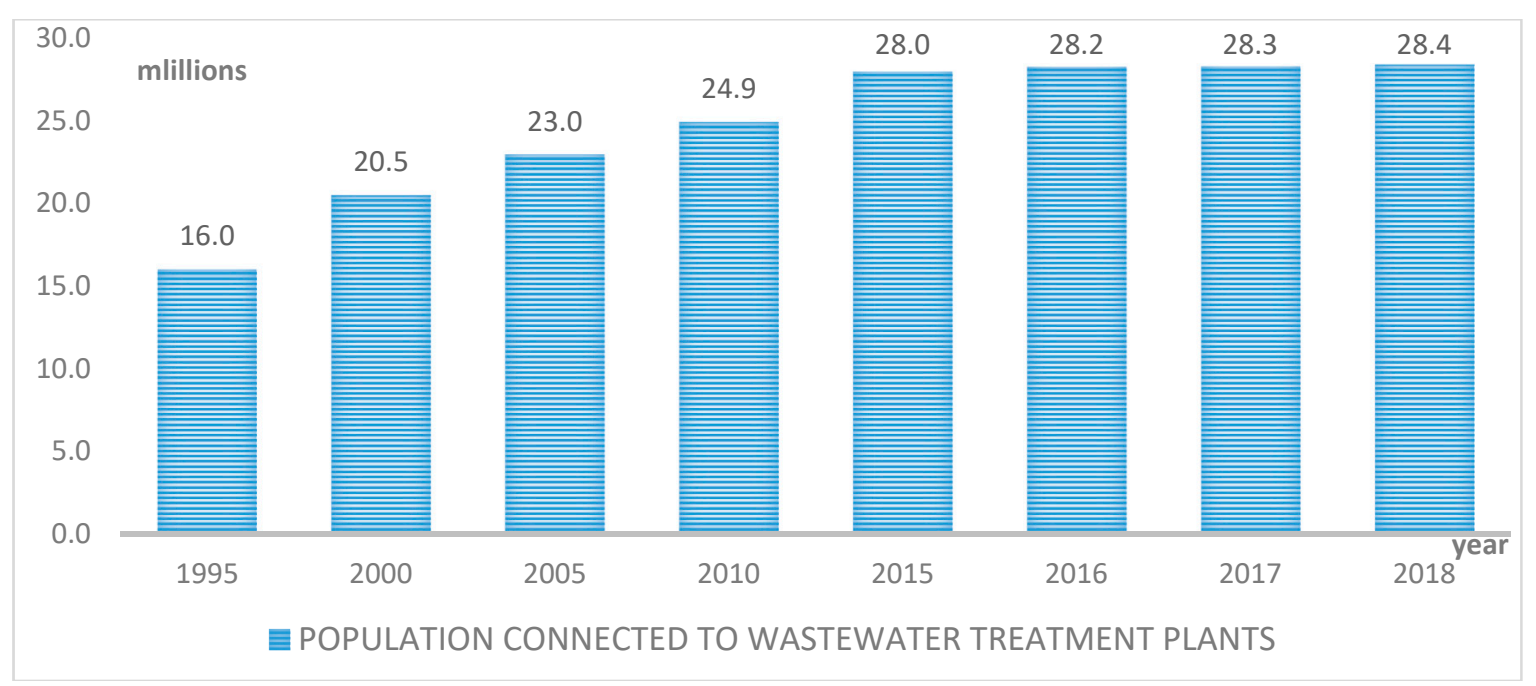

(a)

Figure 3. Cont. 


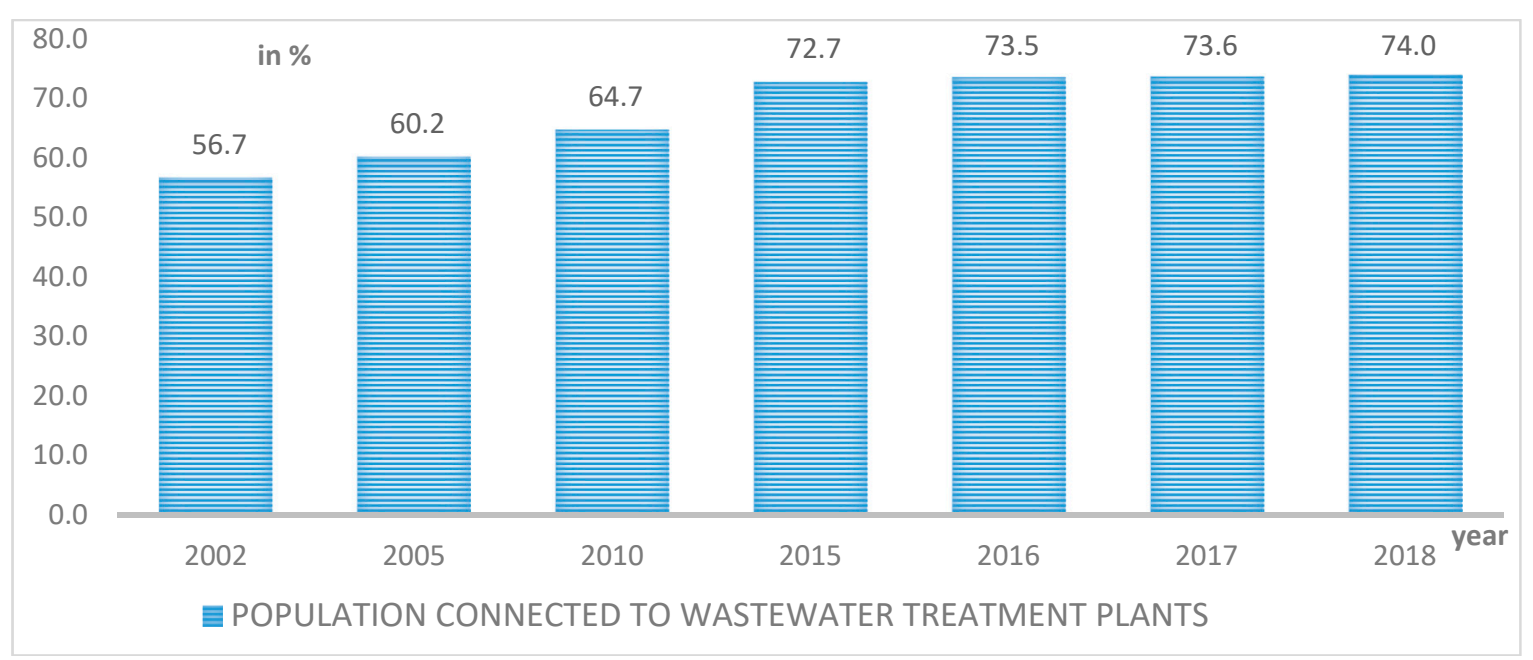

(b)

Figure 3. a. Number of people using sewage treatment plants in Poland from 2000 to 2018. b. Share of people using sewage treatment plants in Poland from 2000 to 2018. Source: [48] Table 55(100) and [49] table: Municipal Wastewater Treatment Plant, Under group: Population Connected to Wastewater Treatment Plant and under group: Population Connected to Wastewater Treatment Plant as a \% of total population.

In Poland, however, some mechanisms that aim to reduce the dynamics of the increase in the amount of urban wastewater have been shown to work. For instance, after 1992, regulations were introduced in Poland requiring full metering of water intake by households [51] (p. 26). This was an important factor contributing to the reduction of water consumption and thus the amount of wastewater produced. The next factor is the rising prices of water (before 1990 the price of water from public waterlines was at the same level in the whole country, which was about $01 \mathrm{PLN} / \mathrm{m}^{3}$ of cold water. The price of water was then increased and in 1995 reached the average level of $0.58 \mathrm{PLN} / \mathrm{m}^{3}$, in $2000-1.52 \mathrm{PLN} / \mathrm{m}^{3}, 2005-2.27 \mathrm{PLN} / \mathrm{m}^{3}, 2010-2.29 \mathrm{PLN} / \mathrm{m}^{3}, 2015-3.73$ and $2018-3.96 \mathrm{PLN} / \mathrm{m}^{3}$. This was an average price; however, it differed hugely depending on provinces. In 2018, the cheapest 1 $\mathrm{m}^{3}$ of cold water from public supply cost 1.3 PLN and the most expensive was 57.34 PLN (all data in current prices) [52].

Showing this data in percentages, the rise of cold water prices in Poland reached 583\% between the years 1995-2018 (data before the year 1995 are difficult to compare because of very high inflation rates during this time. In the year 1995 there was a currency devaluation, so data can be more easily compared). Another important process could be the exploitation of the technological gap. After a period of economic transition, modern energy- and water-saving appliances were immediately introduced, and there was a relatively rapid exchange (or purchase) of household appliances. In both trends, it is important to distinguish between urban areas (about $95 \%$ of city dwellers connected to wastewater plants) and villages (respectively, 42\%) [49].

This is an important area to note for policy-makers. Economic instruments (fees for water) influence the level of water consumption, and this balances the effect caused by the growing number of inhabitants connected to the treatment plant network. The amount of sewage sludge has been growing due to increasing pollution load in municipal wastewater and better treatment processes in wastewater treatment plants (in 2000, only $21 \%$ of sewage was treated biologically with increased biogen removal; in 2018, it was 55.6\% (Table 2). When reaching a certain level of analysis, the dynamics of increasing the amount of sewage sludge will fall. It is hard to determine when this happens, but these processes are visible in our Western neighbors [53].

The presented data and the calculated indicators should be approached with some caution. Due to the possibility of temporary storage, sewage sludge may be processed in a different year than when it 
was produced. In the case of provincial data, the sludge may be processed (recovered or disposed of) in a different province than the one in which they were produced in. However, some conclusions can be drawn. The data provided by Central Statistical Office (CSO) and Local Data Bank (LDB) are not consistent and require high persistence to analyze them. Firstly, in the basic table on the quantities of prepared and processed sewage sludge [50] (Table 58 (103)), the sum of the values given in the subcategories does not equate to the amount of sewage sludge produced. The category "Other", which has a high value and unfortunately shows the failure to operate the sewage sludge management system in Poland, is omitted. This category appears only in the analyses for the provinces and in Eurostat data. It is also not included in the data contained in the LDB. In addition, LDB uses the categories "Stored together" and "Time-stored" only when examining the data. It is possible that the LDB category "stored together" corresponds to the CSO's category of "stored", whereas the second LDB category, "stored temporarily", in the statistical yearbook of the CSO is not present in this table. The analysis of the basic data is difficult to understand; it becomes unreadable and should serve not only to assess the current state and analyze trends from the past, but also to predict for the future and provide a basis for decision making.

Data inconsistencies were also identified in the Strategy for Municipal Sewage Sludge Treatment for the period 2019-2022, indicating three sources of data on sewage sludge and how to process it [41] (p. 31):

1. $\mathrm{CSO}$;

2. Reports on the implementation of the National Municipal Wastewater Treatment Programme (data include only NMWTP investments);

3. The product and packaging and Waste Management Database, which was launched in 2018.

Data from all mentioned registers differ from each other. This analysis comprises CSO and LDB data, which are collected by Central Statistical Office and are transferred to Eurostat.

The amount of sewage sludge increases in total (Table 2 and Figure 2); there is a general decreasing trend in production of industrial sewage sludge, and a growing trend in terms of municipal sewage sludge. The apparent problem is the sewage sludge accumulated in the wastewater treatment plants in Poland, and despite a significant decline in its amount since 2005, it is still 219,300 tons of dry substance (d.s.) in the case of municipal sewage treatment plants and more than 6,000,000 t. d.s. from industrial wastewater treatment plants (of which a significant proportion has been stored in the Malopolska region and comes from the metallurgical industry). The amount of sewage sludge from industry accumulated in the wastewater treatment plant areas and production plant areas (factories) is 16 times larger than the present production of sewage sludge per year. This strongly influences the environment and population health; therefore, it should be a subject for a sewage sludge strategy. Sewage sludge is still landfilled, although currently the European Union forbids this practice (in Poland in 2018 more than 10,000 t. of municipal sewage sludge were stored yearly, and an additional 50,000 t. were stored temporarily. However, it should be noted down that more than 218,000 t. of municipal sewage sludge was accumulated by the year 2018, and only $872 \mathrm{t}$. of it was treated in 2018) [54].

Although long-term data show a decrease in the amount of sewage sludge produced by 2010 and its growth since that year, the structure of the sewage sludge produced remains important. The amount of industrial sewage sludge is declining, whereas the amount of municipal sewage sludge is growing (Figure 2).

However, in the forecasts contained in the National Waste Management Plan from 2002 [55], in 2014, 700,000 t. d.s. of sewage sludge were forecast to be produced in Poland in municipal wastewater treatment plants. However, 583,100 t. d.s. of sewage sludge were produced by municipal sewage treatment plants in 2018, which is significantly lower than the forecast, though the sector faces enormous problems with the management of MSS.

In terms of the analysis of the method of treatment of MSS, in 2000-2005, the dominant form of the management of the MSS was storage (40\%), but this declined according to official data to $2.6 \%$ 
(nominally with 150,000 t. d.s. to 15,000 t. d.s.). The amount of accumulated sludge also decreased and is three times lower (from 675,000 t. d.s. to 219,000 t. d.s.). However, the problem still exists because only 5700 tons were processed in 2016, $2700 \mathrm{t}$. in 2017 and only $872 \mathrm{t}$. in 2018, which means that if the amount of accumulated MSS does not increase, its used will take, on average, 5-10 years. The amount of temporary storage MSS (up to three years) has increased, and currently is almost double compared to 2005 (Table 2 and Figure 4). These data indicate the apparent effectiveness of the prohibition on storage (since 2016); however, they do not include sludge that are being processed (an important issue is the question of when exactly sludge becomes waste).

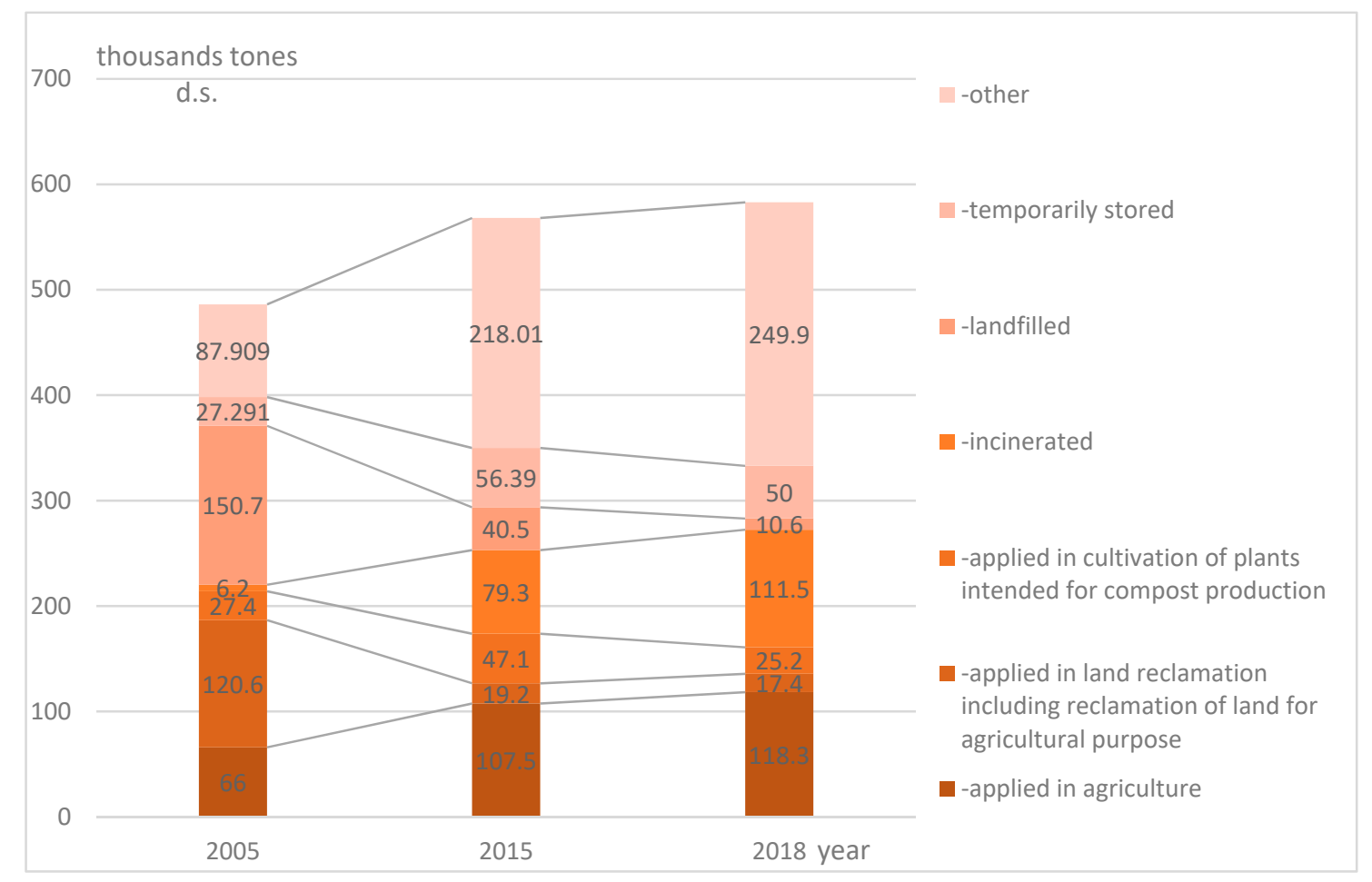

Figure 4. Generation and treatment of municipal sewage sludge in Poland between 2005 and 2018 (thousands tons of dry substance). Source: Own development based on [48] Table 59 (104).

At present, there are two methods of treating MSS that are used almost at the same level: agricultural application (66,000 t. d.s. in 2005 and 118,000 t. d.s. in 2018) and incineration (5.900 t. d.s. in 2000 and 111,500 t. d.s. in 2018) (Figures 4 and 5). The amount of thermally transformed sludge increased significantly from $1.6 \%$ to $18 \%$ and it is expected that this share will increase (Figure 5). There were 11 sewage sludge thermal utilization plants (mono-incinerators) with the projected processing capacity of 160,000 t. d.s./year in 2018 [38]. However, when planning new plants for the combustion of sewage sludge, it should be taken into account that MSS quantity will stabilize at some level, and may even start to drop slightly. The management of sewage sludge should be regionally balanced and based on reliable statistical data.

Figures 4 and 5 show how the "other" category (which includes the transfer of MSS to other authorized bodies for their management, the use of sediment for cultivation of plants not intended for direct consumption, and the use of sediment in R3 processes, i.e., recycling or regeneration of organic substances which are not used as solvents (including composting and other biological transformation processes; R12 - the replacement of waste for submission to any of the processes listed in Items R 1 to R 11 according to Classification from the Waste Act 2013. Appendix 1 Non-exhaustive list of recovery processes) grew significantly, reaching 44\% in Poland in 2017, while in other European countries, the share of the "other" category is small [53]. This is evidence of the failure of the sewage sludge 
management system as municipal sewage sludge is not disposed on wastewater treatment plants but transported to other installations.

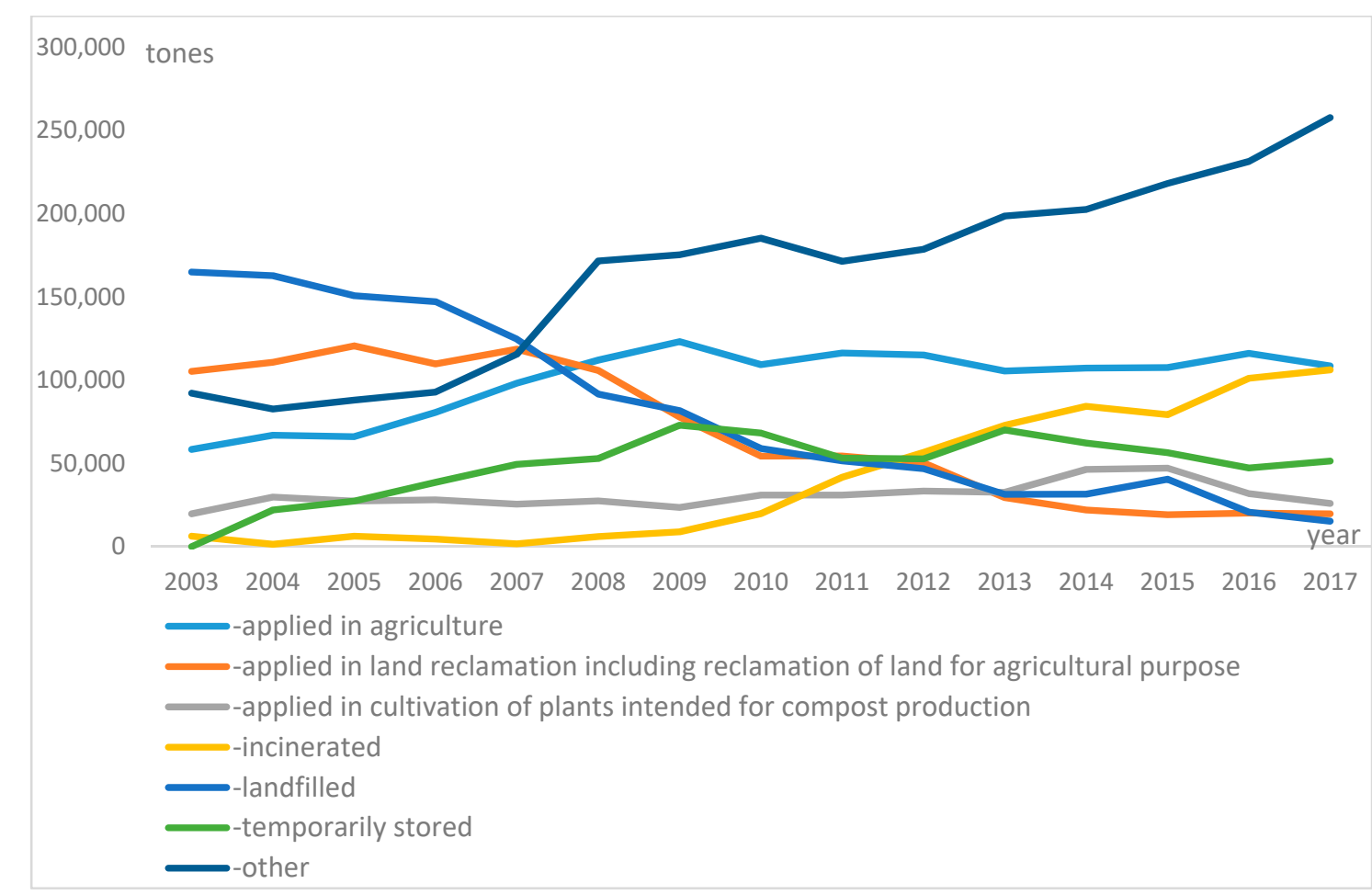

Figure 5. Directions of sewage sludge development in Poland from 2003 to 2017 (t. d.s.). Source: Own development based on [49] table: TREATMENT of URBAN WASTE WATER, under Group: sludge produced during the year.

Although the comparison of the EU countries is not the subject of this paper, it seems to be important to support the analysis by developing basic data on MSS production and disposal in selected countries (Figure 6). Nine countries were chosen for the analysis, and there were two main criteria: availability of Eurostat data and representation of two groups of countries: EU-15 (the old UE members) and EU-12 (the new EU members, accession after 2004). At the first glance, there is a huge difference in the amount of sewage sludge produced, firstly between the representatives of EU-15 and EU-12 countries, and secondly among the EU-12 countries themselves. The amount of generated sewage sludge is mainly affected by the amount of treated municipal sewage (the number of residents served, the condition of the sewage system) and technologies used for wastewater treatment. It is worth noting that in UE-12 countries, the amount of sewage sludge will grow with the increase of citizen number served by wastewater treatment plants and improvement of treatment technology. This process is currently being observed in Poland. 


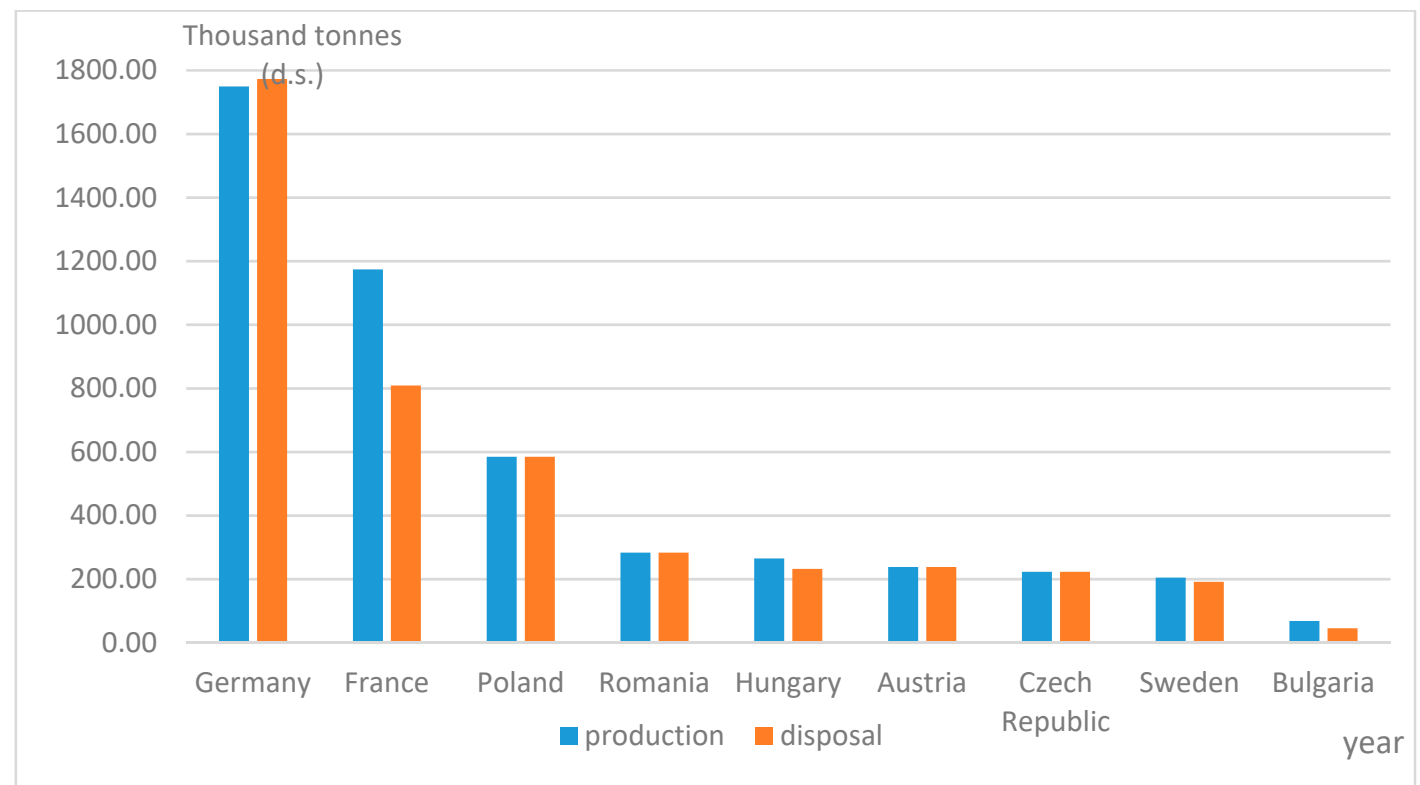

(a)

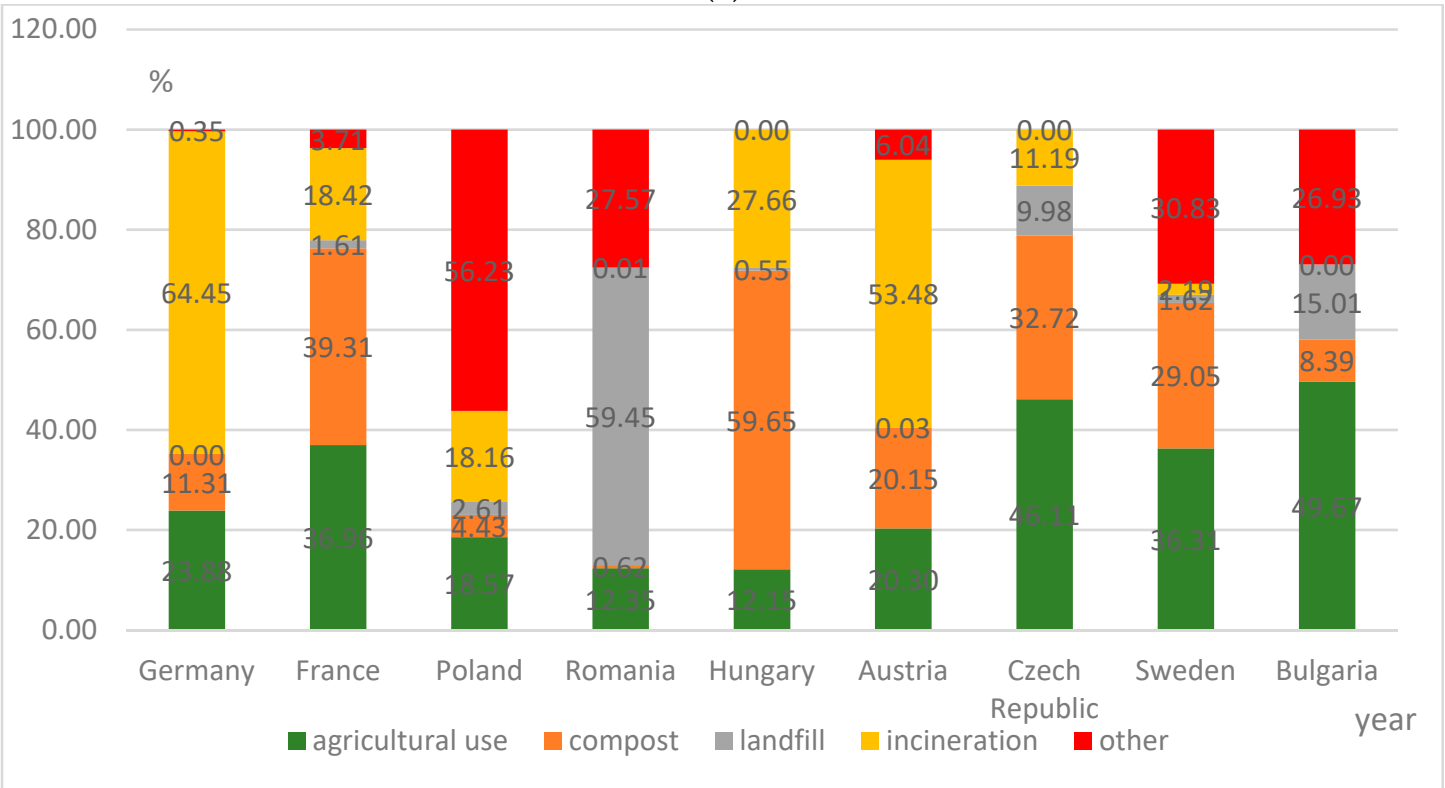

(b)

Figure 6. a. Sewage sludge production and disposal from urban wastewater int the selected EU Countries in years 2016/2017. b. Directions of sewage sludge disposal from urban wastewater int the selected EU Countries in years 2016/2017 Sources: [53,54].

In nominal terms, Germany produces the most MSS and incineration definitely dominates as a disposal method in that country. The share of incineration is relatively high in Austria too. In France, composting and agriculture usage dominates. Sweden has a similar structure but its share of incineration is dramatically low in comparison with the ranking leaders $[53,56]$. Figure 6 shows the very high share of "other" category in Poland, which proves that its system of MSS fails. There are some obstacles that make it impossible to treat MSS in accordance with legal requirements.

Among the analyzed countries, Romania has the worst situation because landfill is still the most common method of MSS disposal and the category "other" has a significant share too. To sum up, there is no single model of MSS management in the EU but the share of incineration seems to be growing, and some countries like Germany or Hungary place a strong emphasis on developing it. 
Poland, too, introduces the same direction for sewage sludge disposal. The utilization of MSS in sewage sludge incineration plants creates a possibility of phosphorus recovery from ashes. Although this process is still very costly, the EU seems to put a strong emphasis on developing it, mainly through $R \& D$, and it is likely to become more efficient in the near future $[57,58]$. Phosphorus is one of the critical raw material (CRM), as there is almost no natural sources of it in Europe. Both phosphorus recovery from ashes and by agriculture use supports the introduction of the circular economy rules. However, the issue of trace elements and heavy metals is important to solve [59-65]. Phosphorus recovery from ashes depends strongly on wastewater characterization, and properties of fly ash, which are different and depend, to a large extent, on the type of incineration system $[61,66]$.

According to available data, an average Polish inhabitant produces approximately $14-15 \mathrm{~kg}$ d.s. of MSS, which seems significantly lower than in some EU countries, e.g., Germany or Austria, where the level is ca. $25 \mathrm{~kg}$ d.s./person. However, in these countries, almost the entire population is connected to municipal wastewater treatment plants, so if the amount of MSS produced is converted to the number of people using the municipal sewage treatment plant, then we receive a similar scale indicator in 2017 of $20.7 \mathrm{~kg}$ d.s./person. Therefore, one of the factors determining the amount of sludge generated is the number of inhabitants connected to the treatment plants. Table 2 also lists the indicators converted to the population equivalent (p.e.) as is the case for the implementation of the wastewater directive. The analysis of the data on the realized investments under the NMWTP shows that according to the data from 31 December, 2016, all of the requirements of the directive were satisfied by using 525 agglomerations of the total p.e. of $19,215,925$. Referring to the summary of the population equivalent (p.e.) for Poland, it is currently 38,793,049; the load discharged from agglomerations satisfying the requirements of the directive accounted for $49.5 \%$ of the total load generated by all agglomerations. It is estimated that at the end of 2021, all commitments should meet 1036 agglomerations of the total p.e. of $31,026,978$, which represents $80.0 \%$ of the total generated by the p.e. agglomerations [66] (p. 7).

Given the divergence of the interpretations of when sludge form an integral part of the wastewater undergoing treatment processes within a technological thrust in the treatment plant and when the sludge become waste (that is, when they can be classified as waste of the appropriate code and thus can be processed within the meaning of the waste regulations), it can be assumed that the stream of actual generated sewage sludge is higher than recorded in national statistics [38] (p. 55, footnote 16).

The Strategy for Municipal Sewage Sludge Treatment for the years 2019-2022 is not a comprehensive document and does not generally indicate directions for further actions. Although the main goal of this strategy is properly defined as "Prevention and reduction of the amount of sewage sludge resulting from wastewater treatment plants and the elimination of the production of municipal sewage sludge" it does not offer ready solutions, but instead only suggests some directions to be considered [41] (p. 34). The strategy fails to address the real problems existing in Poland too. It should take a holistic and horizontal approach with a focus on circular economy goals.

It should be clearly defined that sewage sludge is not only a waste but it also contains important nutrients and can be a zero emission source of energy.

The strategy should also clarify if energy and nutrients recovery are the main priority for Poland, and the directions of actions, investments and R\&D. The main existing problems like technologies for the pre-treatment of sewage sludge, lack of dewatering and drying installation in smaller wastewater treatment plants must be solved at the beginning as they can become the main obstacle for further processes (e.g., incineration). It is important that the MSS moved to the dryer installations get the highest possible dry matter (dry substance) content achieved by mechanical dewatering. The next issue that should be clarified in the strategy is the directions for MSS treatment.

The number and localizations of MSS incineration plants ought to be listed. The decisions about investments should support the local and regional resource circulation regarding specific local conditions and transport costs of primary treated sewage sludge.

An increase in the share of heavy metals and the concentration of various types of micro-pollutants $[58,61,67-70]$ with a significant health risk and environment impacts as well as 
the visible trend of limiting heavy metal concentrations in agricultural disposal are clear premises for the development of thermal methods. This aspect should be widely analyzed as part of the above mentioned strategy. However, the examples of other EU countries prove [53,56], the diverse strategy to be a good solution, as it promotes agriculture use with biogas recovery during the composting process, incineration, and co-incineration.

Analyzing the current situation in Poland, the processing capacity of incineration plants will increase, both in the process of co-incineration and of mono- incineration. At present, there are 11 sewage sludge thermal use plants and 42 installations registered as incinerators or co-incinerators in Poland. Further investments are already under way [40] (p. 361 and the following pages).

Sewage sludge incineration plants are the most costly types when compared with other methods of sewage sludge management, and are still six times more expensive when compared with agricultural use in Poland (in comparison in Germany the costs of thermal utilization are twice higher than agriculture use) [71]. Therefore, it is important to consider the issue of building sewage sludge incineration plants, also in the context of ensuring the quality of the incineration feed (quality and hydration of sewage sludge). On the other hand, ashes from sewage sludge incineration plants, are characterized by the highest content of phosphorus and the highest recovery potential of over $90 \%[57,58]$. Phosphorus is listed as the critical raw material (CRM), and its recovery is efficient only from sewage sludge incineration plants (mono-incinerators), while co-incineration excludes this possibility [46] (s. 90-92).

For countries like Poland, where landfilling of sewage sludge was for past decades the main method of its disposal, the incineration with phosphorus recovery is an interesting alterative [46] (s. 89), [67]. Large water and sewage companies in Poland implement comprehensive model solutions related to the management of sewage sludge. The costs of advanced technological processes are high, but a scale effect exists here. In large wastewater treatment plants, it pays off to use advanced technologies, and high efficiency and effectiveness can be achieved [72].

Smaller sewage treatment plants pose a problem, as without systemic support, they are not able to face the issues of sewage sludge management. This distorts statistics because several large installations in the region support a significant amount of sewage sludge, but dozens of small installations do not meet the requirements. In the statistics, everything is correct, but the problem does not disappear [73]. Small sewage treatment plants without stabilization produce (or should produce, under typical process conditions) three times more dehydrated sludge than large objects using fermentation and dewatering [73]. The poor quality of sewage sludge after primary processing complicates or prevents proper arrangement.

If sewage sludge is properly prepared at small plants, it can be accepted in regional installations for use. However, this incurs additional transport costs, which prevent the transport of untreated, not dewatered sewage sludge.

Perhaps the use of local agricultural composting plants could be an interesting solution as long as the safety of the process and products is guaranteed. The relatively low costs of agricultural sewage sludge treatment in Poland means that, from an economic point of view, this solution should be considered. However, the method of MSS treatment should be based on the local conditions, wastewater characteristics, methods of primary treatment, and the quality of the final product, which understandably must comply with all of the relevant regulations.

The statistical data show that present solutions are not sufficient, proved by a large share of the other category in sewage sludge disposal. It means that some difficulties appear in practice, which make sewage sludge treatment impossible in accordance with the law.

The threat is serious enough that without system solutions at the national level, locally-selected solutions may not be optimal and will contribute to an increase in the costs of sewage sludge management. 
Therefore, when planning the regional and national levels of sewage sludge management, it is necessary to use the synergy and scale effect, and the strategy of dealing with municipal sewage sludge does not meet the requirements of a horizontal and integrated approach.

When planning the sewage sludge management system, organizational and financial issues should also be considered. It seems that the management of sewage sludge on a sewage treatment plant site, together with the recovery of raw materials and energy, is a desirable direction for change. In such an institutional form, obtaining EU funds for co-financing investment projects is easier than in a situation where only primary treatment is conducted in a wastewater treatment plant, and secondary and final treatment is performed by specialist waste management plants (sewage treatment plants operate under conditions of natural monopoly). The organizational and legal forms of entities should also be considered, as local government companies do not fall under certain provisions (e.g., de minimis aid rule) in contrast to private entities operating on a competitive market [40] (p. 417 and the following pages).

In summary, Poland faces a problem with the management of sewage sludge in terms implementing the EU requirements. This is supported by the available statistical data, although they raise some doubts about consistency and comprehensiveness due to the lack of laws or imprecise legal provisions. Sewage sludge has the potential to be used as a means to recover nutrients for plants (phosphorus) and energy, which is in line with the concept of the circular economy. However, to solve the existing problems in Poland and to ensure the proper management of municipal sewage sludge, a comprehensive, horizontal, and integrated approach is necessary. The method of sewage sludge preparation and its quality parameters determine the possibility of its subsequent development: recovery or disposal. Thus, various solutions are possible, and the best solution appears to be to plan parallel application depending on local conditions. Large regional installations with economies of scale can support smaller treatment plants, provided that they prepare (process) sludge and transport costs are justified. Dispersed installations of agricultural composting plants could also be used considering health and environmental risks. With increasing prices for the greenhouse gas emission allowance, co-combustion of sewage sludge treated as a zero-emission fuel, despite all technological problems, may also prove to be an interesting option. Although each of the old EU countries uses the dominant form of MSS managing, it seems that planning and developing several forms of MSS disposal depending on regional-local systems would be the best solution.

The usage of MSS as a source of nutrients and energy recovery can be a good example of a circular economy. The holistic approach is needed in designing the whole process of MSS treatment, starting from wastewater collecting, wastewater treatment, sewage sludge primary treatment, energy and heat recovery and finally nutrients recovery and reuse in biological processes. Of course, potential health and environment impact must be taken into account.

The study demonstrated in this paper was based on legal sources, literature review and data from Polish the Central Statistical Office and Local Data Bank Database. Although the accessible data is not comprehensive and complete, some interesting conclusions can be drawn. The data shows that sewage sludge management in Poland faces some serious difficulties. The in-depth analysis confirmed that in bigger agglomerations the process of sewage sludge utilization is generally speaking properly organized. A lot of problems appear though for smaller wastewater treatment plants, mainly concerning mainly primary processing of sewage sludge and the high investment costs of establishing modern sewage sludge utilization plants or installations. There is no scale effect in the case of smaller wastewater treatment plants.

\section{Conclusions}

The aim of this article has been to analyze the municipal sewage sludge management in Poland in the light of the circular economy. To develop this concept, the basic goals and instruments of the circular economy have been synthesized and the current situation of the municipal sewage sludge in 
Poland is described. It contains the summary of legal acts that influence the sector and an analysis of statistical data.

To conclude the conducted analysis, the proper municipal sewage sludge (MSS) management has a great potential to satisfy the circular economy requirements because it enables: (1) energy and heat recovery; (2) the biomass and important nutrients recovery, including phosphorus, which is on the list of the critical raw material (CRM) of the EU; (3) the loop of resource usage; (4) MSS treatment on the place where it was produced or its vicinity (limitation of long distance transport).

The technological progress makes it possible to recover and reuse nutrients accumulated in sewage sludge respecting legal principles and ensuring health and environmental security. The innovative solutions can achieve effectiveness and efficiency thanks to the support of strict legal requirements that the EU imposes in order to ensure safety for citizens and the environment, as well as EU funds.

This study has investigated the condition and challenges for MSS in Poland. After joining the European Union, the focus in Poland was on adjusting the quality of treated wastewater to the requirements of the EU directives. In this process, the issue of sewage sludge was not treated as an integral element of the whole process of water and sewage management. The decisions made regarding the primary and secondary processing conducted most often at sewage treatment plants have a huge impact and determine the possibility of subsequent sludge management.

As illustrated by the synthesis of legal acts in Poland and analysis of statistical data, some conclusions can be made:

- Landfilling was the dominated method for MSS disposal for past decades in Poland, and stricter EU regulations forced its changes;

- The amount of MSS produced in Poland is constantly increasing, because of the acceleration of socio-economic development, the rise of the wastewater treatment plants number, and the improvement of treatment technology (a higher share of biological treatment with increased biogen removal) and the growth of the resident number connected to municipal wastewater lines;

- Treatment of accumulated MSS poses the next major challenge in this area;

- Industrial sewage sludge produced and especially accumulated in Poland should be the subject for researchers and should be incorporated into Strategy for Sewage Sludge Treatment;

- There is no single dedicated legal act concerning MSS; the issues connected with MSS are regulated by a number of legal acts from various fields (The Water Act, The Waste Act and related Regulations, acts connected with fertilizers and renewable energy); the acts and regulations must be unified and clarified to offer detailed and precise solutions concerning responsibility of entities engaged in the process of MSS agriculture usage, costs and scope of MSS testing and its monitoring;

- The Strategy for Municipal Sewage Sludge Treatment was adopted only in the year 1998, however, this is not a coherent and comprehensive document. Although it recommends that both the amount of MSS processed before entering the environment and the amount of MSS incinerated should increase, there is no recommendation for how to implement these changes. Moreover, no specific criteria have been set for the selection method of MSS treatment and disposal;

- There are three sources of MSS data: CSO, Reports on the Implementation of the National Municipal Wastewater Treatment Programme and the Product and Packaging and Waste Management Database. However, the data are not fully comparable and this is an area for further improvement;

- The data analyzed show that among methods of MSS disposal the "other" category has an extremely high share. They also show the failure of Poland's MSS management system. Some obstacles exist that limit the lawful MSS treatment and disposal. That is a subject for further research and a new complex MSS strategy;

- There are delays in investments of MSS incineration plants, which negatively affects the proper MSS management. Out of 41 planned sewage sludge incineration plants in Poland, only 11 were constructed in 2018; 
- Outdated methods of sludge pre-treatment in small wastewater treatment plants render the proper final sludge disposal impossible or excessively difficult.

- On the whole wastewater treatment plants in big cities address the problem of sewage sludge correctly, although they also encounter various difficulties.

Further research in Poland should focus on developing the horizontal and regional based solutions for MSS management to ensure innovative but cost efficient solutions are developed that are tailored to the regional scale, which will inevitably support the implementation of the circular economy.

Funding: The publication has been financed by the Ministry of Science and Higher Education within the "Regional Initiative of Excellence" Programme for 2019-2022. Project no.: 021/RID/2018/19. Total financing: 11897 131,40 PLN.

Acknowledgments: This research is part of the project - Rev 4.0 - Socio-economic Consequences of the Fourth Industrial Revolution ("Regional Initiative of Excellence" Programme for 2019-2022), the key research area: Models of public goods and services production and distribution. I would like to thank to the anonymous reviewers for their constructive comments, which have led to meaningful improvements in the paper.

Conflicts of Interest: The author declare no conflict of interest.

\section{References}

1. Kula, E. History of Environmental Economic Thought; Psychology Press: London, UK; New York, NY, USA, 1998.

2. Pichlak, M. Gospodarka o obiegu zamkniętym-Model koncepcyjny. Ekonomista 2018, 3, 335-346. (In Polish)

3. Ayres, R.U.; Kneese, A.V. Production, Consumption, and Externalities. Am. Econ. Rev. 1969, 59, $282-297$.

4. Considine, T.J.; Larson, D. The environment as a factor of production. J. Environ. Econ. Manag. 2006, 52, 645-662. [CrossRef]

5. Żylicz, T. Trwały rozwój jako podstawa polskiej polityki ekologicznej. Ekonomia i Środowisko 2001, 1, 57-69. (In Polish)

6. Andersen, M.S. An introductory note on the environmental economics of the circular economy. Sustain. Sci. 2006, 2, 133-140. [CrossRef]

7. Leontief, W. The economy as a circular flow. Struct. Chang. Econ. Dyn. 1991, 2, 181-212. [CrossRef]

8. Geissdoerfer, M.; Savaget, P.; Bocken, N.M.; Hultink, E.J. The Circular Economy-A new sustainability paradigm? J. Clean. Prod. 2017, 143, 757-768. [CrossRef]

9. Commoner, B. The Closing Circle: Nature, Man, and Technology; Knopf Doubleday Publishing Group: New York, NY, USA, 2014.

10. Lyle, J.T. Regenerative Design for Sustainable Development; John Wiley \& Sons INC.: New York, NY, USA; Brisbane, Australia; Chichester, UK; Toronto, YTO, Canada; Singapore; Weinheim, Germany, 1994.

11. Graedel, T.E. On the Concept of Industrial Ecology. Annu. Rev. Energy Environ. 1996, 21, 69-98. [CrossRef]

12. McDonough, W.; Braungart, M. Cradle to Cradle: Remaking the Way We Make Things; North Point Press a division of Farrar, Straus and Giroux: New York, NY, USA, 2002.

13. Benyus, J.M. Biomimicry: Innovation Inspired by Nature; Harper Perennial: New York, NY, USA, 2002.

14. Stahel, W. The Performance Economy; Palgrave Macmillan: London, UK; New York, NY, USA, 2010.

15. Pauli, G.A. The Blue Economy: 10 Years, 100 Innovations, 100 Million Jobs; Paradigm Publications: Taos, New Mexico, 2010.

16. Stahel, W.R. The circular economy. Nature 2016, 531, 435-438. [CrossRef]

17. Towards a Circular Economy: Business Rationale for an Accelerated Transition. Ellen MacArthur Foundation, 2015. Available online: https://www.ellenmacarthurfoundation.org/publications/towardsa-circular-economy-business-rationale-for-an-accelerated-transition (accessed on 17 October 2018).

18. Communication from the Commission to the European Parliament, the Council, the European Economic and Social Committee and the Committee of the Regions Towards a Circular Economy: A zero waste programme for Europe. COM/2014/0398 final. Available online: https://eur-lex.europa.eu/legal-content/EN/TXT/?uri= CELEX:52014DC0398\&qid=1584385869098 (accessed on 17 October 2018).

19. EEA Report No 6/2017 Circular by Design_Products in the Circular Economy; Publications Office of the European Union 2017: Luxembourg. Available online: https://www.eea.europa.eu/publications/circular-bydesign (accessed on 17 October 2018). 
20. Kalisz, M. Prognozy zmian w gospodarce osadami ściekowymi. Wodociagi Kanalizacja, 2007. Available online: http://e-czytelnia.abrys.pl/wodociagi-kanalizacja/2007-3-269/oczyszczanie-sciekow-2387/ prognozy-zmian-w-gospodarce-osadami-sciekowymi-7024 (accessed on 13 September 2019). (In Polish).

21. NWMP2002-National Waste Management Plan 2002-Krajowy Plan Gospodarki Odpadami 2002; MP. 2003, nr 11. Poz. 159 Uchwała Rady Ministrów nr 219 z dnia 29 października 2002 roku w sprawie krajowego planu gospodarki odpadami. Available online: http://prawo.sejm.gov.pl/isap.nsf/DocDetails.xsp? id=WMP20030110159 (accessed on 26 February 2019). (In Polish)

22. The Water Act; Ustawa z Dnia 20 Lipca 2017 r-Prawo Wodne; O.J. 2017 poz. 1566. Available online: http://prawo.sejm.gov.pl/isap.nsf/DocDetails.xsp?id=WDU20170001566 (accessed on 26 February 2019). (In Polish)

23. The Waste Act -Ustawa z Dnia 14 Grudnia 2012 r. o Odpadach; O.J. 2013 poz. 21. Available online: http://prawo.sejm.gov.pl/isap.nsf/DocDetails.xsp?id=WDU20130000021 (accessed on 26 February 2019). (In Polish)

24. The Act on Collective Water Supply and Collective Sewage Disposal - Ustawa z dnia 7 czerwca 2001 r. o zbiorowym zaopatrzeniu w wodę i zbiorowym odprowadzaniu ścieków; O.J. 2001, poz. 747. Available online: http://prawo.sejm.gov.pl/isap.nsf/DocDetails.xsp?id=WDU20010720747 (accessed on 26 February 2019). (In Polish)

25. The Regulation of the Minister of Environment on the on the Municipal Sewage Sludge (own translation)Rozporzadzenie Ministra Środowiska z dnia 6 lutego 2015 r. w sprawie komunalnych osadów ściekowych; O.J. 2015 poz. 257. Available online: http://prawo.sejm.gov.pl/isap.nsf/DocDetails.xsp?id=WDU20150000257 (accessed on 26 February 2019). (In Polish)

26. The Regulation of the Minister of Economy of 16 July 2015 on the Criteria of Waste Admission for Landfill (own translation). -Rozporzadzenie Ministra Gospodarki z dnia 16 lipca 2015 r. w sprawie dopuszczania odpadów do składowania na składowiskach; O.J. 2015, poz. 1277. Available online: http://isap.sejm.gov.pl/isap.nsf/ DocDetails.xsp?id=WDU20150001277 (accessed on 26 February 2019). (In Polish)

27. The Regulation of the Minister of Environment on the R10 recovery process (own translation) Rozporzadzenie Ministra Środowiska z dnia 20 stycznia 2015 r. w sprawie procesu odzysku R10; O.J. 2015 poz. 132. Available online: http://prawo.sejm.gov.pl/isap.nsf/DocDetails.xsp?id=WDU20150000132, (accessed on 26 February 2019). (In Polish)

28. The Regulation of the Minister of Environment on the Recovery of Waste Outside Treatment Installations and Equipment (own translation) - Rozporządzenie Ministra Środowiska z dnia 11 maja 2015 r. w sprawie odzysku odpadów poza instalacjami i urządzeniami; O.J. 2015 poz. 796. Available online: http://prawo.sejm.gov.pl/isap. nsf/DocDetails.xsp?id=WDU20150000796 (accessed on 26 February 2019). (In Polish)

29. The Regulation of the Minister of Agriculture and Rural Development on the Implementation of Certain Provisions of the Act on Fertilizers and Fertilization (own translation) - Rozporzadzenie Ministra Rolnictwa $i$ Rozwoju Wsi z dnia 18 czerwca 2008 r. w sprawie wykonania niektórych przepisów ustawy o nawozach i nawożeniu; O.J. 2008, poz. 765. Available online: http://prawo.sejm.gov.pl/isap.nsf/DocDetails.xsp?id=WDU20081180756 (accessed on 26 February 2019). (In Polish)

30. The Regulation of the Minister of Climate on the Waste Catalogue (own translation) - Rozporzadzenie Ministra Klimatu z dnia 2 stycznia 2020 r. w sprawie katalogu odpadów; O.J. 2020 poz. 10. Available online: http://isip.sejm.gov.pl/isap.nsf/DocDetails.xsp?id=WDU20200000010 (accessed on 7 April 2020). (In Polish)

31. The Regulation of the Minister of Economy of type of Waste that can be Disposed in the Landfill in a Non-selective Manner (own translation) - Rozporzadzenie Ministra Gospodarki z dnia 16 stycznia 2015 r. w sprawie rodzajów odpadów, które moga być składowane na składowisku odpadów w sposób nieselektywny; O.J. 2015 poz. 110. Available online: http://prawo.sejm.gov.pl/isap.nsf/DocDetails.xsp?id=WDU20150000110 (accessed on 26 February 2019). (In Polish) 
32. The Regulation of the Minister of Maritime Affairs and Inland Navigation on substances that are particularly harmful to the aquatic environment and the conditions that must be met when discharging sewage into waters or into the ground, as well as when discharging rainwater or snowmelt into waters or water facilities (own translation) - Rozporzadzenie Ministra Gospodarki Morskiej i Żeglugi Śródlądowej z dnia 12 lipca 2019 r. w sprawie substancji szczególnie szkodliwych dla środowiska wodnego oraz warunków, jakie należy spetnić przy wprowadzaniu do wód lub do ziemi ścieków, a także przy odprowadzaniu wód opadowych lub roztopowych do wód lub do urzadzeń wodnych. O.J. 2019 poz. 1311. Available online: http://prawo.sejm.gov.pl/isap.nsf/DocDetails.xsp?id=WDU20190001211 (accessed on 7 April 2020). (In Polish)

33. The Regulation of Minister of Construction of 14 July 2006 on the Manner of Fulfilling the Obligations of Industrial Sewage Supplier and on Conditions for the Introduction Wastewater to Sewerage Systems (own translation) - Rozporzadzenie Ministra Budownictwa z dnia 14 lipca 2006 r. w sprawie sposobu realizacji obowiazków dostawców ścieków przemysłowych oraz warunków wprowadzania ścieków do urzadzeń kanalizacyjnych; O.J. 2006 nr 136 poz. 964. Available online: http://prawo.sejm.gov.pl/isap.nsf/DocDetails.xsp?id=WDU20061360964 (accessed on 26 February 2019). (In Polish)

34. The Regulation of the Minister of Environment on Methods of Conducting the Assessment of Soil Surface Pollution (own translation) -Rozporzadzenie Ministra Środowiska z dnia 1 września 2016 r. w sprawie sposobu prowadzenia oceny zanieczyszczenia powierzchni ziemi; O.J. 2016 poz. 1395. Available online: http://prawo.sejm. gov.pl/isap.nsf/DocDetails.xsp?id=WDU20160001395 (accessed on 26 February 2019). (In Polish)

35. The Regulation of the Minister of Environment on Technical Conditions which must be Fulfilled to Energy Recovered in the Waste Incineration (own translation) - Rozporzadzenie Ministra Środowiska z dnia 8 czerwca 2016 r. w sprawie warunków technicznych kwalifikowania części energii odzyskanej z termicznego przekształcania odpadów; O.J. 2016, poz. 847. Available online: http://prawo.sejm.gov.pl/isap.nsf/DocDetails.xsp?id=WDU20160000847 (accessed on 26 February 2019). (In Polish)

36. The Regulation of the Minister of Environment on Emission Standards for Certain Types of Installations, Fuel Combustion Installations and Waste Incineration or Co-incineration Plants (own translation) Rozporzadzenie Ministra Środowiska z dnia 1 marca 2018 r. w sprawie standardów emisyjnych dla niektórych rodzajów instalacji, źródeł spalania paliw oraz urządzeń spalania lub wspótspalania odpadów; O.J. 2018 poz. 680. Available online: http://prawo.sejm.gov.pl/isap.nsf/search.xsp?status=A\&publisher=WDU\&year=2018\& position=680 (accessed on 26 February 2019). (In Polish)

37. Directive 2009/28/EC of the European Parliament and of the Council of 23 April 2009 on the Promotion of the Use of Energy from Renewable Sources and Amending and Subsequently Repealing Directives 2001/77/EC and 2003/30/EC (Text with EEA Relevance). Available online: http://data.europa.eu/eli/dir/2009/28/oj/eng (accessed on 26 February 2019).

38. NWMP2022-National Waste Management Plan 2022-Krajowy Plan Gospodarki Odpadami 2022. Available online: https://bip.mos.gov.pl/strategie-plany-programy/krajowy-plan-gospodarki-odpadami/ krajowy-plan-gospodarki-odpadami-2022/krajowy-plan-gospodarki-odpadami-2022-przyjety-przezrade-ministrow-uchwala-nr-88-z-dnia-1-lipca-2016-r/ (accessed on 26 February 2019). (In Polish)

39. Bień, J. Komunalne Osady Ściekowe-Zagospodarowanie Energetyczne i Przyrodnicze; Wydawnictwo Politechniki Częstochowskiej: Częstochowa, Poland, 2015. (In Polish)

40. Wójtowicz, A.; Jędrzejewski, C.; Bieniowski, M.; Darul, H. Modelowe Rozwiazania w Gospodarce Osadowej; Bydgoski Dom Wydawniczy Margrafsen: Bydgoszcz, Poland, 2013. (In Polish)

41. SMSST2018 - Strategy for Municipal Sewage Sludge Treatment for the years 2019-2022. Strategia Postepowania z Komunalnymi Osadami Ściekowymi NA Lata 2019-2022; Ministerstwo Środowiska: Warszawa, Poland, 2018. Available online: https://www.gov.pl/attachment/2846e2b3-68c7-46eb-b36e-7643e81efd9a (accessed on 26 February 2019). (In Polish)

42. NWPP2014-National Waste Prevention Programme. Krajowy Program, Zapobiegania Powstawaniu Odpadów. Available online: https://bip.mos.gov.pl/strategie-plany-programy/krajowy-programzapobiegania-powstawaniu-odpadow/h/11170/051cde29/ (accessed on 26 February 2019). (In Polish)

43. PEnP2009—The Polish Energy Policy_Polityka Energetyczna Polski do 2030 Roku; Ministerstwo Gospodarki: Warszawa, Poland, 2009. Available online: https://www.gov.pl/web/aktywa-panstwowe/politykaenergetyczna-polski-do-2030-roku (accessed on 26 February 2019). (In Polish)

44. NMWTP2003-National Municipal Wastewater Treatment Programme-Krajowy Program Oczyszczania Ścieków Komunalnych; Ministerstwo Środowiska: Warszawa, Poland, 2003. 
45. ANMWTP2017-Actualisation of National Municipal Wastewater Treatment Programme-Aktualizacja Krajowego Programu Oczyszczania Ścieków Komunalnych; KZGW: Warszawa, Poland, 2017. Available online: https://www.kzgw.gov.pl/index.php/pl/materialy-informacyjne/programy/krajowyprogram-oczyszczania-sciekow-komunalnych (accessed on 26 February 2019). (In Polish)

46. Bień, J. Ekspertyza, Która Będzie Stanowić Materiat Bazowy do Opracowania Strategii Postępowania z Komunalnymi Osadami Ściekowymi Na Lata 2014-2020; Politechnika Częstochowska: Częstochowa, Poland, 2014. (In Polish)

47. CSO. Ochrona Środowiska w 2017 Roku/Environmental Protection 2017. Stat.gov.pl, 2017. zip file, chapter 3. Available online: https://stat.gov.pl/obszary-tematyczne/srodowisko-energia/srodowisko/ochronasrodowiska-2017,1,18.html (accessed on 14 March 2019).

48. CSO. Ochrona Środowiska w 2019 Roku/Environmental Protection 2019. Stat.gov.pl, 2019. zip file, chapter 3. Available online: https://stat.gov.pl/obszary-tematyczne/srodowisko-energia/srodowisko/ochronasrodowiska-2019,1,20.html (accessed on 11 February 2020).

49. CSO_Bank Danych Lokalnych (BDL)/CSO_Local Data Bank Database (LDB). Available online: https: //bdl.stat.gov.pl/BDL/start (accessed on 20 July 2019).

50. CSO. Ochrona Środowiska w 2018 Roku/Environmental Protection 2018. Stat.gov.pl, 2018. zip file, chapter 3. Available online: https://stat.gov.pl/obszary-tematyczne/srodowisko-energia/srodowisko/ochronasrodowiska-2018,1,19.html (accessed on 11 February 2020).

51. Bartoszczuk, P. Czynniki wpływające na spadek zużycia wody z wodociagów w Polsce. Studia i Materiały POLSKIEGO STOWARZYSZENIA ZARZ DZANIA WIEDZA. Stud. Proc. Pol. Assoc. Knowl. Manag. 2006, 7, 25-34. (In Polish)

52. Metr sześcienny wody od 1,30 zł do 57,34 zł. Wody Polskie zapowiadaja procesy sąowe. Available online: https://www.money.pl/gospodarka/wiadomosci/artykul/metr-szescienny-wody-od-1-30zl-do-57-34-zl,83,0,2416211.html (accessed on 11 February 2020).

53. Rosiek, K. Directions of management of municipal sewage sludge in the European Union. Ekon. Środowisko/Econ. Environ. 2019, 3, 34-54. [CrossRef]

54. Sewage sludge production and disposal from urban wastewater in the selected EU Countries in years 2016/2017. Source: Own development based on Eurostat, Sewage sludge production and disposal from urban wastewater (in dry substance (d.s). Available online: https://ec.europa.eu/eurostat/tgm/table.do?tab= table\&plugin $=1 \&$ language $=$ en\&pcode $=$ ten00030 (accessed on 7 April 2020).

55. NWMP2002, National Waste Management Plan 2002-Krajowy Plan Gospodarki Odpadami 2002. Available online: https://www.prawo.pl/akty/m-p-2003-11-159,17010502.html (accessed on 7 April 2020).

56. Kelessidis, A.; Stasinakis, A. Comparative study of the methods used for treatment and final disposal of sewage sludge in European countries. Waste Manag. 2012, 32, 1186-1195. [CrossRef] [PubMed]

57. Kasprzyk, M.; Gajewska, M.; Molendowska, S. Możliwości odzysku fosforu z odcieków, osadów ściekowych i popiołów po termicznym przekształcaniu osadów ściekowych. Inż. Ekol. 2017, 18, 4.

58. Antonkiewicz, J.; Popławska, A.; Kołodziej, B.; Ciarkowska, K.; Gambuś, F.; Bryk, M.; Babula, J. Application of ash and municipal sewage sludge as macronutrient sources in sustainable plant biomass production. J. Environ. Manage. 2020, 264, 110450. [CrossRef] [PubMed]

59. Przydatek, G.; Wota, A.K. Analysis of the comprehensive management of sewage sludge in Poland. J. Mater. Cycles Waste Manag. 2020, 22, 80-88. [CrossRef]

60. Raheem, A.; Sikarwar, V.; He, J.; Dastyar, W.; Dionysiou, D.D. Opportunities and challenges in sustainable treatment and resource reuse of sewage sludge: A review. Chem. Eng. J. 2018, 337, 616-641. [CrossRef]

61. Cheng, Y.; Oleszek, S.; Shiota, K.; Oshita, K.; Takaoka, M. Comparison of sewage sludge mono-incinerators: Mass balance and distribution of heavy metals in step grate and fluidized bed incinerators. Waste Manag. 2020, 105, 575-585. [CrossRef]

62. Fijałkowski, K.; Rorat, A.; Grobelak, A.; Kacprzak, M. The presence of contaminations in sewage sludge The current situation. J. Environ. Manage. 2017, 203, 1126-1136. [CrossRef]

63. Alvarenga, P.; Mourinha, C.; Farto, M.; Santos, T.; Palma, P.; Sengo, J.; Morais, M.C.; Cunha-Queda, C. Sewage sludge, compost and other representative organic wastes as agricultural soil amendments: Benefits versus limiting factors. Waste Manag. 2015, 40, 44-52. [CrossRef]

64. Kominko, H.; Gorazda, K.; Wzorek, Z. Potentiality of sewage sludge-based organo-mineral fertilizer production in Poland considering nutrient value, heavy metal content and phytotoxicity for rapeseed crops. J. Environ. Manage. 2019, 248, 109283. [CrossRef] 
65. Tarpani, R.R.Z.; Alfonsín, C.; Hospido, A.; Azapagic, A. Life cycle environmental impacts of sewage sludge treatment methods for resource recovery considering ecotoxicity of heavy metals and pharmaceutical and personal care products. J. Environ. Manage. 2020, 260, 109643. [CrossRef] [PubMed]

66. Master Plan dla Wdrażania Dyrektywy Rady 91/271/EWG Opracowany na Podstawie AKPOŚK 2017; KZGW: Warszawa, Poland, 2017.

67. Smol, M.; Kulczycka, J.; Kowalski, Z. Sewage sludge ash (SSA) from large and small incineration plants as a potential source of phosphorus - Polish case study. J. Environ. Manage. 2016, 184, 617-628. [CrossRef] [PubMed]

68. Final Report, Part I: Overview Report-Environmental, Economic and Social Impacts of the Use of Sewage Sludge on Land. Milieu Ltd., WRc and RPA for the European Commission, DG Environment, 2010. Available online: http://ec.europa.eu/environment/archives/waste/sludge/pdf/part_i_report.pdf (accessed on 7 April 2020).

69. Final Report, Part II: Report on Options and Impacts-Environmental, economic and social impacts of the use of sewage sludge on land. Milieu Ltd., WRc and RPA for the European Commission, DG Environment, 2010. Available online: http://ec.europa.eu/environment/archives/waste/sludge/pdf/part_ii_report.pdf (accessed on 7 April 2020).

70. Final Raport Part III: Project Interim Reports, Environmental, economic and social impacts of the use of sewage sludge on land. Milieu Ltd., WRc and RPA for the European Commission, DG Environment, 2010. Available online: http://ec.europa.eu/environment/archives/waste/sludge/pdf/part_iii_report.pdf (accessed on 7 April 2020).

71. Henclik, A.; Kulczycka, J.; Gorazda, K.; Wzorek, Z. Uwarunkowania gospodarki osadami ściekowymi w Polsce i Niemczech. Inż. Ochr. Śr. 2014, 17, 185-198. (In Polish)

72. Rybicki, S.; Łuszczek, B. Efektywność termicznego przekształcania osadów na tle innych metod zagospodarowania na przykładzie wybranej oczyszczalni ścieków. Inzynieria Ochr. Śr. 2014, 17, 377-391. (In Polish)

73. Wójtowicz, A. I co dalej z osadami? Wodociagi Kanaliz 2016. Available online: http://e-czytelnia.abrys.pl/ wodociagi-kanalizacja/2016-1-900/temat-numeru-10730/i-co-dalej-z-osadami-21021 (accessed on 11 February 2019). (In Polish).

(C) 2020 by the author. Licensee MDPI, Basel, Switzerland. This article is an open access article distributed under the terms and conditions of the Creative Commons Attribution (CC BY) license (http://creativecommons.org/licenses/by/4.0/). 